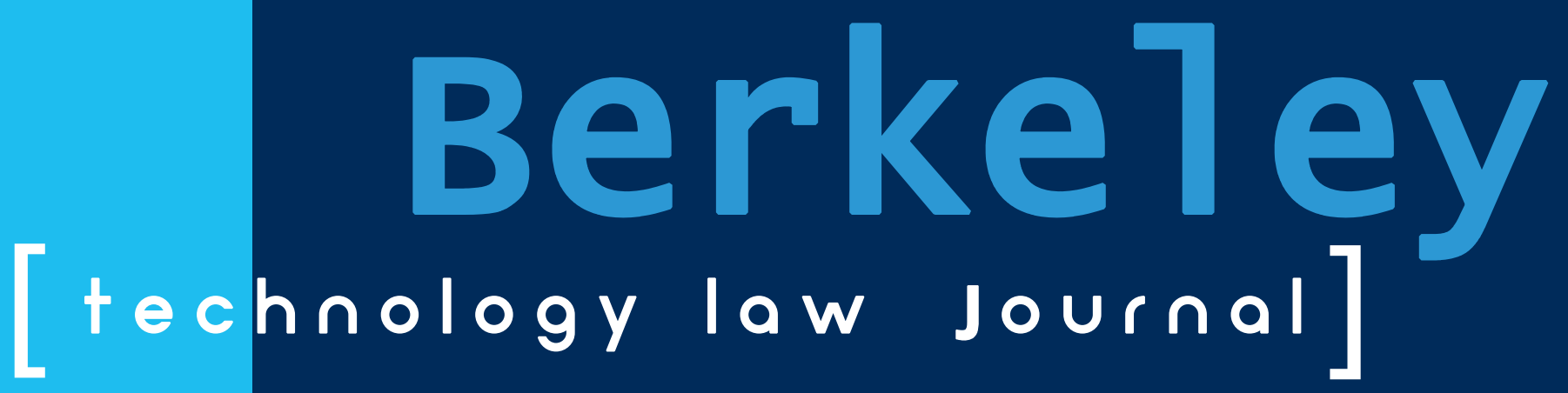

117 Can You See Me Now? Toward Reasonable Standards for Law Enforcement Access to Location Data That Congress Could Enact

Stephanie K. Pell \& Christopher Soghoian

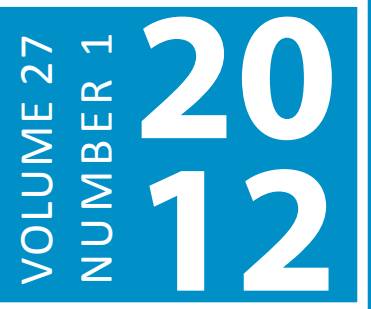

UNIVERSITY OF CALIFORNIA, BERKELEY SCHOOL OF LAW 


\title{
Can You SeE Me Now?: TOWARD REASONABLE STANDARDS FOR LAW ENFORCEMENT ACCESS TO LOCATION DATA THAT CONGRESS COULD ENACT
}

\author{
Stephanie K. Pell ${ }^{\dagger}$ \& Christopher Soghoian ${ }^{\dagger \dagger}$
}

\begin{abstract}
The use of location information by law enforcement agencies is common and becoming more so as technological improvements enable collection of more accurate and precise location data. The legal mystery surrounding the proper law enforcement access standard for prospective location data remains unsolved. This mystery, along with conflicting rulings over the appropriate law enforcement access standards for both prospective and historical location data, has created a messy, inconsistent legal landscape where even judges in the same district may require law enforcement to meet different standards to compel location data. As courts struggle with these intertwined technology, privacy, and legal issues, some judges are expressing concern over the scope of the harms, from specific and personal to general and social, presented by unfettered government collection and use of location data and how to respond to those harms. Judges have sought to communicate the scope and gravity of these concerns through direct references to Orwell's dystopia in 1984, as well as suggestive allusions to the "panoptic effect" observed by Jeremy Bentham and his later interpreters, such as Michel Foucault. Some have gone on to suggest that privacy issues raised by law enforcement access to location data might be addressed more effectively by the legislature.

This Article proposes a legislative model for law enforcement access standards and downstream privacy protections for location information. This proposal attempts to (1) articulate clear rules for courts to apply and law enforcement agents and industry to follow; and (2) strike a reasonable balance among the interests of law enforcement, privacy, and industry with the ultimate goal of improving the position of all concerned when measured against the current state of the law.
\end{abstract}

(C) 2012 Stephanie K. Pell \& Christopher Soghoian.

$\dagger$ Principal, SKP Strategies, LLC; former Counsel to the House Judiciary Committee; former Senior Counsel to the Deputy Attorney General, U.S. Department of Justice; former Counsel to the Assistant Attorney General, National Security Division, U.S. Department of Justice; and former Assistant U.S. Attorney, Southern District of Florida. Email: stephanie@stephaniepell.net

H Graduate Fellow, Center for Applied Cybersecurity Research; Ph.D. Candidate, School of Informatics and Computing, Indiana University. Email: chris@soghoian.net.

The authors would like to thank Derek Bambauer, Catherine Crump, Susan Freiwald, Jim Green, Albert Gidari, Markus Jakobsson, Paul Ohm, Christopher Slobogin, and Magistrate Judge Stephen Wm. Smith for their feedback and assistance. The authors would also like to thank the attendees of the Privacy Law Scholars Conference, where this Article was presented in the summer of 2011. 


\section{TABLE OF CONTENTS}

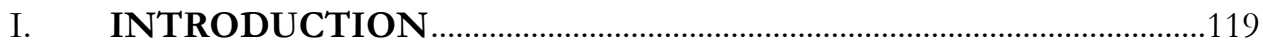

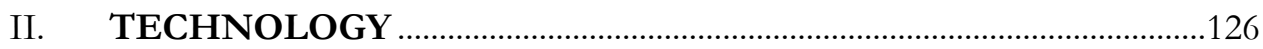

A. A Brief Introduction to Cell Phone TeChNology ...............126

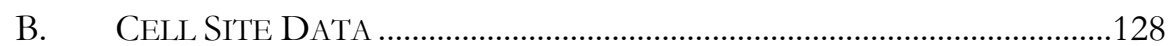

C. Global Positioning SYSTEM ("GPS”) ...............................................128

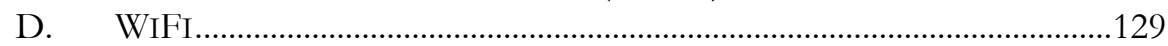

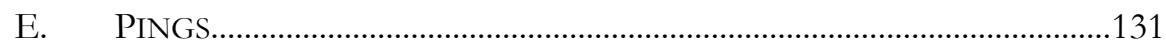

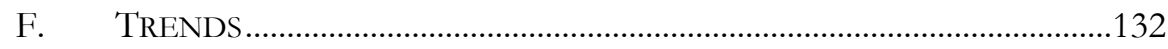

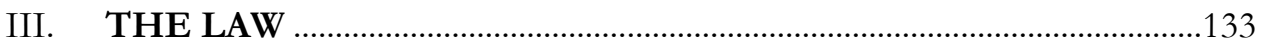

A. Legal Background For ReAL-Time or "Prospective"

CELL SITE DATA ……………………....................................................134

1. The DOJ's Interpretation of the Standard for Obtaining Prospective Cell Site Data ...............................................................135

2. Judicial Resistance to the Government's Use of Hybrid Orders..............137

3. Divergent Interpretations of the Standard for Requiring Disclosure of Prospective Cell Site Data Create Legal Uncertainty ...................................................................................139

B. LEGAL BACKGROUND FOR HISTORICAL CELl SITE DATA.................141

1. The DOJ's Interpretation of the Standard for Obtaining Historical Cell Site Data .....................................................................142

2. Judicial Interpretation of the Standard for Obtaining Historical Cell Site Data .....

a) The Third Circuit Finds That Magistrate Judges Have the Discretion To Require Probable Cause .........143

b) The D.C. Circuit's "Mosaic Theory”..................................145

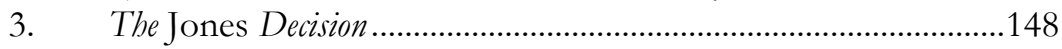

4. The Importance of Legislative Clarity in the Face of Rapid Technological Change ..........................................................................150

C. Questions Raised by THE TwO EXISTING STANDARDS FOR COMPELLING DISCLOSURE OF LOCATION DATA.........................151

1. What Does a "D" Order Require the Government To Show? ?.............151

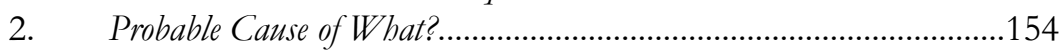

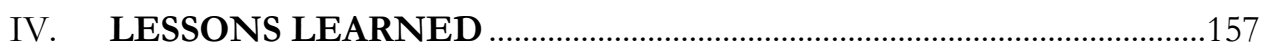

A. ACQuiring Facts To Make GoOd POlicy Is DifFicult .............157

B. THE SINGULAR ADVOCACY FOCUS ON LAW ENFORCEMENT STANDARDS HAS NARROWED A DISCUSSION THAT SHOULD INCLUDE MINIMIZATION AND OTHER "DOWNSTREAM" PRIVACY PROTECTIONS. 
C. THE POLARIZED Views OF LAW ENFORCEMENT AND

PRIVACY ADVOCATES MAKE CONSENSUS BUILDING

DIFFICULT

V. WHAT IS THE HARM, AND WHO CAN ADDRESS IT

MOST EFFECTIVELY?

A. THE GOVERnMENT'S GAZE AND THE PANOPTIC EFFECT.................164

VI. LEGISLATIVE PROPOSAL ...............................................................174

A. OVERARCHING PRINCIPLES..............................................................175

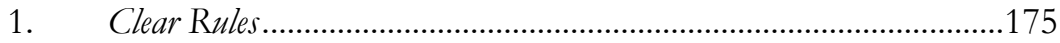

2. Technology Neutrality ..................................................................176

3. Standards Alone Will Not Achieve the Appropriate Balance...............176

4. Insistence on a Single Location Standard Is

"A Foolish Consistency"....................................................................177

B. HOW TO DEFINE LOCATION INFORMATION FOR PURPOSES OF AMENDING THE ECPA ……………………...............................178

C. A STANDARD FOR LAW ENFORCEMENT COMPELLED

DISCLOSURES OF HISTORICAL LOCATION DATA...................................180

D. A STANDARD FOR LAW ENFORCEMENT COMPELLED

Disclosures of PROSPECTIVE LOCATION DATA ...............................181

E. Post Access Rules And "Downstream” Privacy

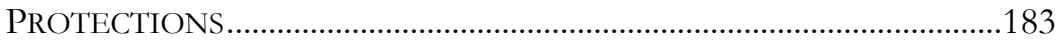

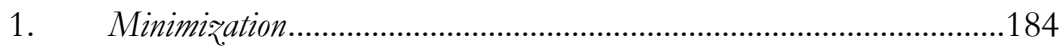

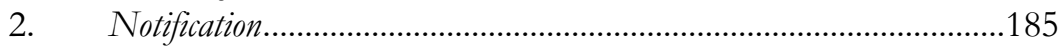

3. Surveillance Statistics .....................................................................188

VII. CONCLUSION

193

\section{INTRODUCTION}

Over several months in 2008, a gang of five men, described as the "Scarecrow Bandits" in media reports, committed or attempted twenty-one violent "takeover-style" bank robberies in the Dallas area. ${ }^{1}$ FBI agents investigating the case contacted cellular telephone companies and obtained phone number logs to determine which telephones had been near the banks around the time of the heists. By searching these voluminous records, agents discovered that two phones had made calls near twelve of the robbed banks. ${ }^{2}$

1. See Press Release, Dep't of Justice, Federal Jury Convicts Scarecrow Bandits on Bank Robbery and Firearm Offenses (Aug. 13, 2009), http://www.justice.gov/usao/txn/ PressRel09/scarecrow_bandits_convict_pr.html.

2. See Declan McCullagh, Feds Push for Tracking Cell Phones, CNET NEws (Feb. 11, 2010), http://news.cnet.com/8301-13578_3-10451518-38.html. 
Similarly, after two men robbed a Connecticut bank in July 2008, law enforcement agents obtained historical cell tower logs revealing 180 different phone numbers that had made or received calls near the bank at the time of the robbery. Although these logs led police to two brothers, both of whom were soon arrested, the police also obtained and retained location information associated with 178 innocent people who will never learn that their phone companies disclosed information to police. ${ }^{3}$

Law enforcement agencies_already using location information in their investigations - are likely to increase their reliance on such information as technology improves. ${ }^{4}$ This is true of requests for all types of mobile device location data, whether historical or real-time (prospective), ${ }^{5}$ in conducting criminal investigations and locating fugitives. For example, primarily due to the use of location information, the average time needed for the U.S. Marshals Service to find a fugitive has dropped from forty-two days to only two. ${ }^{6}$ In recent congressional testimony, a senior Department of Justice ("DOJ") official explained how a homicide detective and his partner in Prince George's County, Maryland, used "cell tower [location] information" to pursue a man wanted for a triple murder, capturing him in only nine hours. ${ }^{7}$ Having this information "immediately accessible" allowed the marshals to deploy "available law enforcement resources [effectively] ... without placing officers, or the public, at undue risk." 8 Clearly, location information has become a powerful investigative tool in support of a range of law enforcement responsibilities.'

3. See Declan McCullagh, ACLU: FBI Used 'Dragnet'-Style Warrantless Cell Tracking, CNET NEWS (June 22, 2010), http:// news.cnet.com/8301-31921_3-20008444-281.html.

4. A more technical explanation of location information is presented infra Part II, but for purposes of this example, location information means information about or derived from a portable device, such as a cellular phone, that reveals the location of the device either approximately or with a high degree of precision.

5. McCullagh, supra note 2 (“Obtaining location details is now 'commonplace,' says $\mathrm{Al}$ Gidari, a partner in the Seattle offices of Perkins Coie who represents wireless carriers.”).

6. See Going Dark: Lawful Electronic Surveillance in the Face of New Technologies: Hearing Before the Subcomm. on Crime, Terrorism and Homeland Security of the H. Comm. on the Judiciary, 112th Cong. 2 (2011) (statement of Dr. Susan Landau), available at http://judiciary.house. gov/hearings/pdf/Landau02172011.pdf.

7. The Electronic Communications Privacy Act: Government Perspectives on Protecting Privacy in the Digital Age: Hearing before the S. Comm. on the Judiciary, 112th Cong. 5 (2011) [hereinafter Senate Judiciary 2011 ECPA Hearing] (statement of James A. Baker, Assoc. Deputy Attorney Gen., U.S. Dep't of Justice), available at http://1.usa.gov/IsojNy.

8. Id.

9. See Michael Isikoff, The Snitch in Your Pocket, NewsweEK (Feb. 18, 2010), http:// www.newsweek.com/2010/02/18/the-snitch-in-your-pocket.html. 
The tool proved so effective that the number of "requests"10 to carriers for location information grew "exponentially" over the past few years, with major wireless carriers now receiving thousands of requests per month. ${ }^{11}$ Sprint Nextel received so many requests that it developed a web interface that gave law enforcement direct access to its subscribers' location data. ${ }^{12}$ Law enforcement agents used the website to "ping" Sprint subscribers over eight million times in a single year. ${ }^{13}$

Law enforcement's increased use of location information has spurred courts to scrutinize more closely government applications to compel third parties to disclose location data, as certain magistrate judges question and examine what legal standards govern law enforcement access to historical and prospective location information. Prosecutors "were using the cell phone as a surreptitious tracking device," Judge Smith, a federal magistrate in Houston, told a reporter from Newsweek. "I started asking the U.S. Attorney's Office, What is the legal authority for this? What is the legal standard for getting this information?" 14

All law enforcement demands (not involving voluntary emergency disclosures) for location information, whether seeking historical or prospective data, require some type of court order authorizing a compelled disclosure. ${ }^{15}$ Determining the proper access standard-whether the bigher "probable cause" standard, the lower 18 U.S.C. \2703(d) order requiring "specific and articulable facts" that the information sought is "relevant and

10. The use of the word "requests" in this context means both compelled disclosures of location information where law enforcement presents a third-party provider with a probable cause warrant or an 18 U.S.C. \$ 2703(d) order and voluntary emergency disclosures pursuant to 18 U.S.C. $\int 2702$, where providers may voluntarily share information with law enforcement in the case of an emergency involving danger of death or serious physical injury to any person.

11. Isikoff, supra note 9 ("Albert Gidari, a telecommunications lawyer who represents several wireless providers, tells NEWSWEEK that the companies are now getting 'thousands of these requests per month,' and the amount has grown 'exponentially' over the past few years.").

12. Chief Judge Kozinski, in a dissent in which he stressed the importance of maintaining Fourth Amendment protections in the face of increasingly sophisticated forms of government surveillance, noted that " $[\mathrm{w}]$ hen requests for cell phone location information have become so numerous that the telephone company must develop a self-service website so that law enforcement agents can retrieve user data from the comfort of their desks, we can safely say that 'such dragnet-type law enforcement practices' are already in use." United States v. Pineda-Moreno, 617 F.3d 1120, 1126 (9th Cir. 2010) (Kozinski, J., dissenting from denial of rehearing en banc).

13. Id. at 1125 .

14. See Isikoff, supra note 9.

15. See discussion infra Sections III.A and III.B. 
material to an ongoing criminal investigation,"16 or some other "hybrid" standard-is anything but clear under current law. As various courts struggle to apply the Electronic Communications Privacy Act ("ECPA") 17 and the Fourth Amendment to compelled disclosures of location information, a messy, inconsistent legal landscape has emerged: "within the same judicial district, you might have two magistrates who disagree and issue contrary orders for the standard upon which to disclose that [location] information."18 Indeed, the degree of confusion over the appropriate standard to apply to location information is increasing and has spread across judicial districts. ${ }^{19}$

The House Judiciary Committee's Subcommittee on the Constitution, Civil Rights, and Civil Liberties began to respond to this landscape of uncertainty in 2010 by holding a series of ECPA reform hearings, one of which focused specifically on location information. ${ }^{20}$ Prior to the hearings, a

16. 18 U.S.C. \2703(d) (2010).

17. Pub. L. No. 99-508, 100 Stat. 1848 (1986) (codified as amended in scattered sections of 18 U.S.C.). This Article uses the term ECPA to describe the first three titles of the Electronic Communications Privacy Act: Title I ("Interception of Communications and Related Matters"), 100 Stat. at 1848, which amended the Wiretap Act (commonly referring to Title III ("Wiretapping and Electronic Surveillance") of the Omnibus Crime Control and Safe Streets Act of 1968, Pub. L. No. 90-351, tit. III, 82 Stat. 197, 211-25 (codified as amended at 18 U.S.C. SS 2511-2520 (2010))); Title II ("Stored Wire and Electronic Communications and Transactional Records Access"), commonly referred to as the Stored Communications Act (SCA), Pub. L. No. 99-508, tit. II, 100 Stat. 1848, 1860-1868 (codified as amended at 18 U.S.C. $\iint$ 2701-2712 (2010)); and Title III ("Pen Registers and Trap and Trace Devices"), commonly referred to as the Pen/Trap Devices statute, Pub. L. No. 99508, tit. III, 100 Stat. 1848, 1868-1873 (codified as amended at 18 U.S.C. IS 3121-3127 (2010)).

18. Electronic Communications Privacy Act Reform: Hearing Before the Subcomm. on the Constitution, Civil Rights, and Civil Liberties of the H. Comm. on the Judiciary, 111th Cong. 26 (2010) [hereinafter House Judiciary 2010 ECP A Reform Hearing] (written statement of Albert Gidari, Perkins Coie LLP), available at http://judiciary.house.gov/hearings/printers/111th/111-98_ 56271.pdf.

19. See generally ECPA Reform and the Revolution in Location Based Technologies and Services: Hearing Before the Subcomm. on the Constitution, Civil Rights, and Civil Liberties of the H. Comm. on the Judiciary, 111th Cong. 81-85, 93-94 (2010), [hereinafter Location Hearing] (written statement of Judge Stephen Wm. Smith, U.S. Magistrate Judge), available at http://judiciary.house.gov/ hearings/printers/111th/111-109_57082.pdf (summarizing and collecting inconsistent decisions).

20. See Location Hearing, supra note 19. The overarching goal of this hearing was to educate Subcommittee Members about how location-based technologies and services work, and how ECPA's application to location information was creating a state of legal chaos for Magistrate Judges, as well as industry, privacy, and law enforcement stakeholders. In his opening statement at the Location Hearing, Subcommittee Chairman Jerrold Nadler remarked that:

any legislative changes to ECPA must ... sustain the public's confidence in the security of their communications or it [could] harm both the robust 
number of companies and civil liberties groups joined together to create the Digital Due Process ("DDP") Coalition in order to propose principles to guide congressional consideration of ECPA reform. ${ }^{21}$ One principle proposed a new standard for law enforcement access to all types of location information, stating that " $\mathrm{t}]$ he Government should obtain a search warrant based on probable cause before it can track, prospectively or retrospectively, the location of a cell phone or other mobile communications device." 22 This principle seeks to treat historical and prospective location information equally under the law and to require law enforcement to meet a probable cause standard before obtaining access to any location data.

Unfortunately for the privacy community, DDP's probable cause standard is a "non-starter" for law enforcement. One senior DOJ official recently told a Senate Committee that "if an amendment [to the ECPA] were to unduly restrict the ability of law enforcement to quickly and efficiently determine the general location of a terrorist, kidnapper, child predator, computer hacker, or other dangerous criminal, it would have a very real and very human cost." 23 The Department of Justice will indeed resist the imposition of a high, unitary standard for location data access and will likely find no shortage of allies in Congress itself to do so effectively. Even the

market for cell phones and the rapid innovation that is fundamental to the market's health. Because ECPA inevitably involves the interaction of all these important and complex considerations, we are taking the time through multiple hearings to educate ourselves carefully and fully before engaging in legislative action.

...

We are honored to have certain witnesses here today, who are experts in these technologies. They can give us the necessary background to embark upon an understanding of how they work, what types of information and records they can generate and store, and how they can be of assistance to law enforcement in appropriate circumstances.

This initial educational effort is in my view not only warranted, but essential before we undertake any effort at amending or otherwise reforming ECPA. After we hear the terrain described, we will move on to other questions today-namely, how is ECPA currently being applied to these location based technologies and services by the courts?

Id. at 5-6.

21. See About the Issue, Digital Due Process CoAlition (May 5, 2010), http:/ /www. digitaldueprocess.org/index.cfm?objectid=37940370-2551-11DF-8E02000C296BA163; see also House Judiciary 2010 ECPA Reform Hearing, supra note 18, at 12 (written statement of James X. Dempsey, Vice President for Pub. Policy, Ctr. for Democracy \& Tech.), available at http:// judiciary.house.gov/hearings/pdf/Dempsey100505.pdf.

22. See Our Principles, Digital Due Process CoAlition (May 5, 2010), http://www. digitaldueprocess.org/index.cfm?objectid=99629E40-2551-11DF-8E02000C296BA163.

23. Senate Judiciary 2011 ECPA Hearing, supra note 7, at 5 (statement of James A. Baker, Assoc. Deputy Attorney Gen., U.S. Dep't of Justice). 
DDP Coalition acknowledges that ECPA reform must "preserve the 'building blocks' of criminal investigations." 24 In other words, any amendments to the ECPA must continue to enable an investigative system that allows law enforcement to compel the disclosure of various types of non-content information under lower legal standards at the early stages of an investigation. Applying these less stringent standards to non-content information avoids the premature foreclosure of valid investigations, in that it allows agents to pursue early investigative leads and "build up" to the use of more intrusive tools to obtain more sensitive information protected by higher access standards, such as the contents of communications.

But the difficulty with imposing a probable cause standard upon law enforcement access to all location data, as a matter of policy, does not minimize or negate the need for Congress to examine how law enforcement uses location information and to assess the privacy impact of current law enforcement access standards for location information. That examination will reveal an urgent need for Congress to amend the ECPA-both to clarify the law and reestablish the balance of interests among law enforcement, privacy, and industry equities. ${ }^{25}$

The unitary probable cause standard advocated by the privacy community and rejected by law enforcement has led to a stalemate. So, where do we find ourselves? As co-authors who approach ECPA reform from very different backgrounds and perspectives, we recognize the need to propose law enforcement standards for location information that: (1) articulate clear rules for courts to apply and law enforcement agents and industry to follow; and (2) strike a reasonable balance among the interests of law enforcement,

24. Id:; see also House Judiciary 2010 ECPA Reform Hearing, supra note 18, at 16-17 (written statement of James X. Dempsey). The DDP Coalition recognizes that:

$[\mathrm{u}]$ nder current law, government investigators often work their way up the ladder to probable cause, starting with subpoenas for subscriber identifying information and stored transactional data, then moving to court orders under 2703(d) for more detailed transactional data and court orders, based on less than probable cause, for real-time interception of signaling and routing information. Based on analysis of this and other data, they may have probable cause to obtain a search warrant.

Id.

25. Even the Department of Justice "applaud[s] [Senate Judiciary Committee] efforts to undertake a renewed examination of whether [ECPA's] current statutory scheme... adequately protects privacy while at the same time fostering innovation and economic development." See Senate Judiciary 2011 ECPA Hearing, supra note 7, at 6 (testimony of James A. Baker). Mr. Baker further notes that "[i]t is legitimate to have a discussion about our present conceptions of privacy, about judicially-supervised tools the government needs to conduct vital law enforcement and national security investigations, and how our statutes should accommodate both." Id. 
privacy, and industry such that they could be included in legislation that might be passed by Congress. Articulating such a reasonable proposal requires knowledge of technology, law, policy, and politics.

For the purpose of offering a reasonable legislative proposal, we assume as an incontestable value that law enforcement should have access to location information that is necessary and sufficient to ensure the safety of the public by apprehending criminal perpetrators and disrupting future criminal activity-but no more. We also assume as a second and equally uncontestable value that people should be, and know they are, free from any government scrutiny of their location data that is not necessary to that public safety function. Neither of these values is an absolute one. As such, our proposal is neither the most "privacy protective" standard possible, nor the most "law enforcement friendly" standard imaginable. Indeed, what we offer in Part VI is the product of a dialogue between the authors: one a committed privacy advocate and technologist, the other a former federal prosecutor who has both used location tools in that role and considered them from a legislative perspective while working for the House Judiciary Committee.

We believe this Article will advance the debate by proposing a policy framework, including model access standards that will be palatable to all stakeholders insofar as each of their positions will be improved in some appreciable way. Part II of this Article provides a brief background discussion of various current location technologies and the level of location precision they offer. Part III explores the confusion currently plaguing courts over law enforcement access standards to location data and examines what those standards require the government to show. Part IV discusses some "lessons learned" from congressional hearings and advocacy efforts during the 111th Congress, specifically informed by Stephanie's work on the House Judiciary ECPA reform hearings. Part $\mathrm{V}$ examines how courts considering law enforcement access to global positioning system ("GPS") location information have articulated privacy impacts and other social harms using the interpretive frames of Orwell's dystopia in 1984, as well as what has come to be called the "panoptic effect"-the anxious response produced by the presumed omnipresence of the government's gaze. Part V ultimately suggests that location privacy is best addressed by the legislative branch. Finally, Part VI presents a model legislative privacy framework for location information, including law enforcement access standards and other types of "downstream" privacy protections to ensure that, among other things, law enforcement agencies do not retain location data longer than needed for legitimate law enforcement purposes. 


\section{TECHNOLOGY}

Over the past few decades, the mobile phone has evolved from a luxury status symbol to a necessity. By the end of 2010, more than ninety-five percent of the U.S. population subscribed to a mobile telephone service. ${ }^{26}$ As consumers have embraced cellular phones, law enforcement agencies have gained access to several methods through which to obtain both historical and real-time (prospective) location information. Generally speaking, this information can be separated into two categories: passive collection of information incident to the delivery of cellular services, and active surveillance in which information is collected and processed solely to benefit law enforcement agencies. In addition to this distinction, there are several different technologies that can be used to obtain location informationsome highly accurate, others much less so, but with the general direction of innovation tending towards greater precision. The purpose of this Part is to provide the reader with a brief introduction to each of these technologies and the ways in which they can be used to determine or track the location of individuals.

\section{A. A Brief Introduction to Cell Phone Technology}

Unlike conventional "wireline" phones, mobile phones use radio to communicate between the customer's telephone and the carrier's network. Service providers maintain large numbers of radio base stations (also called "cell sites") spread throughout their geographic coverage areas. ${ }^{27}$ These cell sites are generally located on "cell towers" serving geographic areas of varying sizes, depending upon topography and population concentration. Service providers are deploying higher-capacity network architectures, with the potential to provide more precise information regarding a phone user's location.

As part of their normal function, mobile phones periodically identify themselves to the nearest cell site as they move about the coverage area. ${ }^{28}$

26. Wireless Quick Facts, CTIA-WIRELESS ASs'N (2011), http://www.ctia.org/advocacy/ research/index.cfm/aid/10323.

27. Press Release, Informa Telecoms \& Media, The Shape of Mobile Networks Starts To Change as Femtocells Outnumber Macrocells in US (Oct. 21, 2010), http:// femtoforum. org/fema/pressreleases.php?id=269 ("[F]emtocells now outnumber conventional outdoor cell sites in the United States marking a major milestone in the evolution of mobile networks. Conservative estimates suggest there are currently 350,000 femtocells and around 256,000 macrocells in the US. Furthermore by March 2011, there are expected to be at least twice as many femtocells as macrocells in the US.").

28. Location Hearing, supra note 19, at 13 (testimony of Prof. Matt Blaze, Univ. of Pa.) ("Cell phones, as they move and as they are turned on, discover the base station with the 
This enables wireless carriers to know how to reach a particular subscriber's phone when it receives a call. Of course, mobile telephones (as their name suggests) are portable, and so when a phone moves away from the cell site with which it started a call and nearer to a different cell site, the call is "handed over" from one cell site to another without interruption. ${ }^{29}$

Each cell site has a large but fixed maximum capacity that can transmit a limited number of concurrent calls and data streams. In an area with a low number of users (or users who make few calls and who are not heavy users of data services), only a few cell sites will be necessary, and each can serve a large geographical area. In areas with large numbers of active users, however, and particularly those who make heavy use of data services, a carrier will need to place far more cell sites, each serving a smaller geographic area, to compensate for the relatively larger usage burden placed on the local network. ${ }^{30}$ Carriers that do not or cannot deploy more cell sites to cope with increased demand suffer from slow data speeds and frequent dropped calls. ${ }^{31}$ As such, rural areas tend to have fewer cell sites, each with greater service areas, than urban areas, which generally have far more sites that are spaced closer together. Obviously, the proximity of one cell site to another in a geographic area is one factor in the production of more accurate location data.

strongest radio signal and perform a registration process identifying themselves, establishing that the user has a valid cell phone service, and identifying the local base station that is best equipped to process the call by virtue of the strength of its radio signal."); see also id. at 20 (written statement of Prof. Matt Blaze).

29. Id. See generally Nishith D. Tripathi, Jeffrey H. Reed \& Hugh F. VanLandingham, Handoff in Cellular Systems, IEEE PERS. COMM., Dec. 1998, at 26, available at http:/ /www.scss. tcd.ie/Hitesh.Tewari/papers/tripathi98.pdf.

30. Location Hearing, supra note 19, at 15 (testimony of Prof. Matt Blaze) ("[T]oday the limiting factor in how far apart [cell sites] can be is the number of customers they have to serve. And as this technology has exploded, the number of customers in any given area has gone explosively up, particularly in urban and densely populated areas.").

31. For example, one carrier has a reputation for dropped calls in some urban areas like San Francisco, due to the presence of large numbers of tech-savvy users with data-hungry iPhones, combined with the three-year waiting time required by the local authorities to get permission to erect new cell towers (which is often combined with further local obstructionism, whether motivated by opportunistic financial holdups or by NIMBY reactions to cell tower construction from individuals and communities with valuable real estate holdings). See Edward Wyatt, AT\&T and T-Mobile Chiefs Field Skeptical Questions on Capitol Hill, N.Y. Times (May 11, 2011), http://www.nytimes.com/2011/05/12/technology/ 12phone.html ("T-Mobile ads made merciless fun of AT\&T's reputation for dropped calls and sluggish wireless data connections"); MG Siegler, Steve Jobs Continues To Answer the Questions That AT\&T Won't, TECHCRUNCH (July 18, 2010), http://techcrunch.com/2010/ 07/18/steve-jobs-att-2/ ("[Apple CEO Steve Jobs] said that it takes [AT\&T] three years to get approval for a new cell tower in San Francisco. Yes, three years. 'That's the single biggest problem they're having,' Jobs said. . . Jobs also noted at the press conference that it takes 'about three weeks' to add a new cell tower in Texas."). 


\section{B. CELl Site DATA}

Wireless service providers retain detailed logs for diagnostic, billing, and other purposes. These logs reveal the calls and Internet connections made and received by wireless subscribers, as well as detailed technical information regarding the cell sites that were used. ${ }^{32}$ Such logs generally only reveal which particular cell site a phone was near at the time of the call.

Data from multiple towers can be combined to pinpoint (or "triangulate") a phone's latitude and longitude with a high degree of accuracy (typically under fifty meters). ${ }^{33}$ This triangulated cell site data is generally only available prospectively, either due to a 911 call by a subscriber, or because a law enforcement agency has asked a carrier to collect it. Some carriers do routinely track and record triangulated data, and movement toward this practice is a general trend in the industry, although it is not yet the dominant practice, much less the common policy of all companies. ${ }^{34}$ As such, law enforcement agencies can also obtain high-accuracy, triangulated historical data when it is available due to a specific company's data collection practices.

\section{Global Positioning System (“GPS”)}

Many mobile phones now include special hardware that enables the device to receive signals from a constellation of global position satellites. ${ }^{35}$ Software on the phone can use these signals to calculate latitude and longitude,

32. McCullagh, supra note 2 ("Cellular providers tend not to retain moment-bymoment logs of when each mobile device contacts the tower, in part because there's no business reason to store the data, and in part because the storage costs would be prohibitive. They do, however, keep records of what tower is in use when a call is initiated or answered ...."); see also COMPuter Crime \& Intellectual Prop. SeCtion, Dep't of Justice, Retention Periods of Major Cellular Service Providers (2010), available at http://www.wired.com/images_blogs/threatlevel/2011/09/retentionpolicy.pdf (listing, in chart form, data retention periods by the major cellphone carriers).

33. This requires the placement of special radio equipment at each cell site. See generally Location Hearing, supra note 19, at 38-41 (statement of Michael Amarosa, Sr. Vice President for Public Affairs, TruePosition Inc.).

34. Location Hearing, supra note 19, at 26-27 (written statement of Prof. Matt Blaze) ("(Whether locations are routinely tracked and recorded at times other than when calls are made or received depends on the policy of the particular carrier.) ... Some carriers also store frequently updated, highly precise, location information not just when calls are made or received, but about every device as it moves about the networks. Maintaining such detailed records about the locations of phones as they move from place to place makes good engineering sense, and we should expect this trend to continue as part of the natural progression of technology.").

35. This communication is one-way. Phones receive signals from the satellites but do not transmit anything back to them. 
often with a high degree of accuracy (less than twenty-five meters). ${ }^{36}$ Although GPS is often more accurate than any other location technology, there are a few limitations: GPS signals are weak, high-frequency signals that do not penetrate walls, and as a result GPS often does not work when indoors. Moreover, for the same reason, GPS often does not function well in "urban canyons" due to signal deflection off of the sides of tall buildings. Furthermore, the GPS functionality tends to use significant amounts of power, which can lead to shorter battery life. ${ }^{37}$ When GPS functionality is available, wireless carriers can prospectively obtain a device's location, such as when the user dials 911, or when asked to do so by law enforcement agencies. Carriers do not generally have historical GPS data to deliver.

Many smartphones now provide access to the GPS functionality to thirdparty "apps" installed on the devices. As such, app developers and location service providers also have access to users' GPS location data, often far more than the wireless carriers, although this is usually with the user's knowledge and consent. ${ }^{38}$ Law enforcement agencies can compel these location service providers to disclose the historical GPS data in their possession, although prospective disclosures are limited to user-initiated "check-ins," as these companies are usually not able to generate their own GPS queries.

D. WIFI

Many smartphones include wireless internet ("WiFi") functionality, enabling device owners to browse the web at much faster speeds (and without impacting their carrier-imposed data cap) when at home, work, or in many public places. In addition to providing a connection to the Internet, the WiFi connections can also be used to determine the approximate location of the device.

36. Location Hearing, supra note 19, at 55 (attachment to written statement of Michael Amarosa).

37. Letter from Andy Lees, President, Mobile Commc'ns Bus., Microsoft Corp., to Rep. Fred Upton et al. (May 9, 2011), available at http://blogs.technet.com/cfs-file.ashx/_key/ communityserver-blogs-components-weblogfiles/00-00-00-82-95/2451.Consumer-Privacy_2600_-Windows-Phone-7-_2D00_Submission-to-House-Energy-and-Commerce-Committee_2D00_-5.9.2011.pdf ("Windows Phone 7 generally relies upon WiFi access point or cell tower information to determine a phone's approximate location because GPS location data is not always available, and when it is, it can draw more heavily on battery power . ...").

38. If a user "checks in" with a location provider like Foursquare, that location provider will learn their location, but the wireless carrier will not, as the information is sent directly to the location provider. 
Several companies have created databases listing wireless networks and their approximate geographic location. ${ }^{39}$ Initially, these databases were populated with data obtained by driving through the streets of cities around the world, collecting the data with a laptop or other special hardware. ${ }^{40}$ In recent years, however, Google, Apple, and Microsoft have all enlisted the "crowdsourced" assistance of millions of smartphones to collect this data for them. ${ }^{41}$

By determining the available WiFi networks and submitting this list to one of the database providers, applications on the device and the platform mobile vendor (e.g., Google, Apple) can quickly determine the user's approximate location without using GPS, which would consume significantly more battery power. ${ }^{42}$ Location data is increasingly valuable, enough so that the major platform vendors have been "willing to push the envelope on privacy to collect it." ${ }^{43}$ Not only is location data used for maps and

39. See Greg Stirling, Google Ends Street View WiFi Data Collection, May Now Need Other Sources for Location, SEARCH ENGINE LAND (Oct. 20, 2010), http://searchengineland.com/ google-ends-street-view-wifi-data-collection-potentially-needs-other-sources-for-location-53373 ("One of the purposes of collecting WiFi locations is to enable Google to identify user location (on handsets, laptops and PCs to some degree) through triangulation using a database of hotspots."); see also Frequently Asked Questions, SKYHOOK WIRELESS, http://www.skyhookwireless.com/howitworks/faq.php (last visited Mar. 17, 2012) ("Skyhook deploys vehicle-based signal scanning and data collection technologies, a common practice in the digital mapping and data collection industries. These Skyhook-equipped vehicles conduct systematic and comprehensive signal surveys by traveling every public road and highway in targeted coverage areas. These signal surveys capture the data output of individual access points and pair them with a date, time, and location stamp at the point where they are received by the data collection device.").

40. See Brad Stone, Google Says It Collected Private Data by Mistake, N.Y. Times (May 14, 2010), http://www.nytimes.com/2010/05/15/business/15google.html (“[B]ecause of a programming error in 2006, the company had . . been mistakenly collecting snippets of data that happened to be transmitted over non-password protected wi-fi networks that the Google camera cars were passing."); see also Jenna Wortham, Cellphone Locator System Needs No Satellite, N.Y. TIMES (May 31, 2009), available at http://www.nytimes.com/2009/06/01/ technology/start-ups/01locate.html (explaining how the company Skyhook "uses the chaotic patchwork of the world's wi-fi networks, as well as cell towers, as the basis for a location lookup service").

41. Julia Angwin \& Jennifer Valentino-Devries, Apple, Google Collect User Data, WALL ST. J. (Apr. 22, 2011), http://on.wsj.com/zp2Euo (“Apple Inc.'s iPhones and Google Inc.'s Android smartphones regularly transmit their locations back to Apple and Google, respectively ... as part of their race to build massive databases capable of pinpointing people's locations via their cell phones."').

42. See generally John Morris, Apple Trades Privacy for Battery Life, Instead of Protecting Both, CENTER FOR DEMOCRACY \& TECH. (Apr. 22, 2011), https://www.cdt.org/blogs/johnmorris/apple-trades-privacy-battery-life-instead-protecting-both.

43. Miguel Helft, Apple and Google Use Phone Data To Map the World, N.Y. Times (Apr. 25, 2011), https://www.nytimes.com/2011/04/26/technology/26locate.html. 
navigation services on mobile devices, but it is also used to customize advertising aimed at people in a particular place. Such ads are far more lucrative than other ads and are becoming a major portion of the mobile advertising market, which industry experts estimate will be a $\$ 2.5$ billion market by $2015 .^{44}$ Not only do these economic factors encourage companies to collect more location data, but they also encourage the collection of data with greater accuracy, allowing merchants to pitch advertisements to consumers walking past their store, rather than just those in the neighborhood.

E. PINGS

Most of the location information described in this Part is collected in the process of providing wireless voice and data services, or due to users calling 911 or using a location-enabled app on their smartphones. For such information, law enforcement agencies can either request historical data already stored by the provider, or request prospective surveillance that will provide data to the law enforcement agency as soon as the carrier receives it. In either case, the information collection is passive, in that no new data is generated due to the law enforcement surveillance request.

It is also possible, however, for carriers to monitor their customers actively, generating new data specifically in response to a request from law enforcement agencies. In such scenarios, the wireless carriers can covertly "ping" a subscriber's phone in order to locate them when a call is not being made. Such pings can merely reveal the nearest cell site to the subscriber, ${ }^{45}$ or more accurate GPS or triangulated data if requested. ${ }^{46}$ In addition to the

44. Id.

45. See Stone v. State, 941 A.2d 1238, 1244 (Md. Ct. Spec. App. 2008) ("Trooper Bachtell obtained the appellant's cell phone number and contacted his cell phone service provider. At Trooper Bachtell's request, the service provider conducted a 'ping' of the appellant's cell phone, which revealed that the phone was 'within a two mile radius of the Frederick County Detention Center." ").

46. See Comments of CTIA-The Wireless Association on U.S. Department of Justice Petition for Expedited Rulemaking at 17, In re Petition for Expedited Rulemaking To Establish Technical Requirements and Standards Pursuant to Section 107(b) of the Communications Assistance for Law Enforcemenet Act, Docket No. RM-11376 (Fed. Commc'ns Comm'n July 25, 2007), available at http:/ fjallfoss.fcc.gov/ecfs/comment/view?id= 5514711157 ("Law enforcement routinely now requests carriers to continuously 'ping' wireless devices of suspects to locate them when a call is not being made ... so law enforcement can triangulate the precise location of a device and [seek] the location of all associates communicating with a target."); see also Devega v. State, 689 S.E.2d 293, 299 (Ga. 2010) ("[T] which the officers described as sending a signal to the phone to locate it by its global positioning system (GPS). The company complied and informed the police that the phone was moving north on Cobb Parkway."). 
carrier-initiated pings, law enforcement agencies have also performed "low tech" pings by calling a target and hanging up before the phone rang, in order to generate cell site data that could then be requested from the carriers. ${ }^{47}$

\section{F. TRENDS}

The increasing accuracy and use of location data is motivated by the proliferation and advancement of mobile technology, as well as the lucrative commercial market for location-based services and marketing. Within that general context, there are several trends worth noting that suggest that single cell site data will become increasingly accurate. This postulation is particularly significant for evaluating current DOJ policies governing the legal standards for law enforcement's compelled disclosures of prospective location information. ${ }^{48}$

First, in an attempt to "fill the gaps" in their coverage, wireless carriers have, in the past few years, distributed hundreds of thousands of "microcells," "picocells," and "femtocells" to customers, which connect to the user's broadband internet connection and provide cellular connectivity to phones within tens or hundreds of meters. Industry estimates indicate that there are already more than 350,000 femtocells deployed in the United States, as compared to the more than 250,000 traditional carrier cell sites. ${ }^{49}$ As these devices often broadcast a signal no further than a subscriber's home, the accuracy of single cell site location data can in some cases be more accurate than GPS, depending on whether the target is connected to a traditional cell site, or a residential femtocell.

Second, the success of Apple's iPhone and other smartphones has led to a massive increase in the use of data by mobile users. For example, AT\&T has seen an 8,000 percent increase in data traffic between 2007 and $2010 .^{50}$ In response to this increased demand on their networks, carriers are deploying new cell sites and reducing the coverage area of existing towers. ${ }^{51}$ As carriers

47. United States v. Forest, 355 F.3d 942, 947 (6th Cir. 2004) ("In order to reestablish visual contact, a DEA agent dialed Garner's cellular phone (without allowing it to ring) several times that day and used Sprint's computer data to determine which cellular transmission towers were being 'hit' by Garner's phone. This 'cell site data' revealed the general location of Garner.”).

48. See infra Section III.A.1.

49. Press Release, Informa Telecoms \& Media, supra note 27.

50. Dan Meyer, AT\& Filing Provides Interesting Industry Data, RCR WIRELESS (Apr. 25, 2011), http://www.rcrwireless.com/article/20110425/CARRIERS/110429949/att-filingprovides-interesting-industry-data.

51. Tracy Ford, Tower Industry Primed for Growth with Carrier Buildouts, RCR WIRELESS NEWS (Mar. 3, 2010), http://www.rcrwireless.com/ARTICLE/20100303/INFRA STRUCTURE/100309979/tower-industry-primed-for-growth-with-carrier-buildouts ("LTE 
embrace faster $4 \mathrm{G}$ mobile data technologies, they will need even more cell sites, further reducing the coverage area around each tower.

As the coverage area around each traditional cell tower shrinks, and consumers increasingly embrace femtocells in their homes and businesses, single cell site data will become far more accurate-in some cases as good as GPS, and in others pinpointing someone's location to an area the size of a few blocks.

\section{THE LAW}

This Article proposes a policy framework that balances the interests of stakeholders affected by law enforcement access standards for provider-held location information. Before turning to policy proposals, the Article first discusses how law enforcement currently justifies its collection of prospective and historical location data-both under the DOJ's current interpretation of the law and the suggested policy guidance it gives to prosecutors and agents in the field.

This Part describes how the DOJ's and courts' various statutory interpretations have created a set of conflicting standards for law enforcement access to location data. Changes in technology, combined with the instability in the law created by conflicting legal standards for location data, create a critical need for Congress to amend the law to produce a better balance among privacy, law enforcement, and industry equities - a balance that would ideally benefit all stakeholders in some appreciable way. As such, this Part seeks to identify where that balance, as a matter of policy, may lie and how new law enforcement access standards or other "downstream" privacy protections might serve that legislative end. This Part therefore focuses on the policy implications of the current law, not on how the Fourth Amendment might apply to law enforcement access to location data held by a third party. When and under what circumstances the Fourth Amendment might require law enforcement to obtain a warrant to obtain location information from third-party providers remains a contested area of the law $^{52}$ and one that is

is going to be driving revenue for the tower companies ... as a result of the incredible demand supported by LTE $700 \mathrm{MHz}$ spectrum and the resulting splitting and additional coverage and capacity that the carriers are going to have to put in place to meet that demand.").

52. Compare Susan Freiwald, Cell Phone Location Data and the Fourth Amendment: A Question of Law, Not Fact, 70 MD. L. REV. 677, 717 (2011) (arguing that courts should require a warrant for access to location data in all cases because such acquisition is a search under the Fourth Amendment), with Orin S. Kerr, Court Rules That Police Cannot Use Warrants To Obtain Cell Phone Location of Person Who Is Subject of Arrest Warrant, VolokH ConsPIRACY (Aug. 8, 2011), http://volokh.com/2011/08/08/court-rules-that-police-cannot-use-warrantsto-obtain-cell-phone-location-of-person-who-is-subject-of-arrest-warrant/ (arguing that location 
beyond the scope of this Article to reconcile. To the extent that the discussion touches upon Fourth Amendment issues, it does so in the service of describing and developing a policy discussion, not to offer an opinion on the correct application of the Fourth Amendment to location information.

\section{A. Legal Background For Real-Time or "Prospective" CELL SiTE DATA}

Locating the proper law enforcement access standard for prospective location data in the current law is, in some respects, like the quest for the Holy Grail, the search for the fountain of youth, or the hunt for a truly comfortable pair of high heels — one is unlikely to find them. This legal mystery remains unsolved primarily for two reasons. First, the ECPA ${ }^{53}$ - the primary law governing law enforcement access to wire, oral, and electronic communications and other stored subscriber records and information-does not contain the word "location" in any part of the statute or otherwise provide language that could be easily interpreted to cover law enforcement access to real-time location data from third-party providers. ${ }^{54}$ Second, Congress, in a different statute, has only expressed what is insufficient for purposes of law enforcement access to prospective location information from a third-party provider, but not what is either necessary or sufficient for such compelled disclosures. Indeed, the Communications Assistance for Law Enforcement Act ("CALEA") merely instructs that "any information that may disclose the physical location of [a telephone service] subscriber" may

information of phones is not protected by the Fourth Amendment under Smith v. Maryland, 442 U.S. 735 (1979)).

53. See supra note 17.

54. Consider, for example, the testimony of Judge Smith describing the difficulty he and other Magistrate Judges have faced in determining the proper law enforcement access standard for real-time location information:

Moreover, none of the other categories of electronic surveillance seemed to fit. The pen register standard was ruled out by a proviso in a 1994 statute known as CALEA. The wiretap standard did not apply because CSI does not reveal the contents of a communication. The Stored Communications Act (SCA) standard did not seem to apply for two reasons: the definition of "electronic communication" specifically excludes information from a tracking device; and the structure of the SCA was inherently retrospective, allowing access to documents and records already created, as opposed to prospective real time monitoring.

Location Hearing, supra note 19, at 82-83 (footnotes omitted); see also Kevin S. Bankston, Only the DOJ Knows: The Secret Law of Electronic Surveillance, 41 U.S.F. L. REV. 589, 606-09 (2007) (analyzing how the Wiretap Act and Pen/Trap statute do not provide the requisite authority for such "tracking" and the SCA only authorizes retrospective access to previously stored communications content and non-content information). 
not be acquired "solely pursuant to the authority for pen registers and trap and trace devices." 55 Therefore, with respect to a compelled disclosure, if real-time location data cannot be provided to law enforcement "solely pursuant" to a court order for a Pen/Trap device, there must be some further requirement. But that requirement, unfortunately, remains undefined in the law. This exercise in Via Negativa ${ }^{56}$ makes for great scholastic discussions about the incomprehensible character of an ineffable God but it is not very effective as a descriptive tool for discerning a legal standard. At best, it is a rather ineffective inversion of Justice Stewart's famous concurrence in Jacobellis $v$. Obio about the similar difficulty the Court encountered in defining "hard core pornography" with any accuracy: "I know it when I [don't] see it." ${ }^{\prime 57}$ Stated more precisely, if less concisely and memorably, "I'll know it when I can infer its existence and nature by seeing everything that it is not."

\section{The DOJ's Interpretation of the Standard for Obtaining Prospective Cell Site Data}

Lacking clear, affirmative statutory guidance, the DOJ has routinely acquired, since at least 2005, certain categories of "less precise" prospective cell site information through the combination ${ }^{58}$ of two court orders: (1) a Pen/Trap court order pursuant to 18 U.S.C. $\int 3123,{ }^{59}$ and (2) a "D" Order pursuant to 18 U.S.C. $\$ 2703(\mathrm{~d})$, a section of the Stored Communications Act ("SCA") that permits the government to compel the production of non-

55. 47 U.S.C. \1002(a)(2) (2010).

56. The "Via Negativa" is a method of philosophical and theological argument often associated with mysticism, sometimes referred to as "negative" or "apophatic" theology that attempts to describe God or the divine good by negation, specifically in terms of what God is not (apophasis), discerning instead only what may not be said accurately concerning the goodness and perfection(s) of God, which are beyond direct expression. The technique has its roots in several Greek philosophical schools, as well as several Western and Eastern religious traditions. See Negative Theology, THE BlACKWELl DictionARY OF WESTERN Philosophy 465-66 (Nicholas Bunnin \& Jiyuan Yu eds., 2004); see also KAREN Armstrong, The CASE FOR GOD 317 (2009) (describing the potential resurgence of apophatic argument in postmodern theology).

57. Jacobellis v. Ohio, 378 U.S. 184, 197 (1964) (Stewart, J., concurring).

58. See Bankston, supra note 54, at 609-12 (describing the first publically known case where the DOJ articulated the "hybrid theory" in applying for a court order authorizing access to real-time cell site information).

59. 18 U.S.C. \3123(a)(1) (directing that a court "shall enter an ex parte order authorizing the installation and use of a pen register or trap and trace device ... if the court finds that the attorney for the Government [in an application pursuant to 18 U.S.C. $\int 3122(\mathrm{a})(1)$ ] has certified to the court that the information likely to be obtained ... is relevant to an ongoing criminal investigation"). 
content records or information pertaining to a subscriber or customer. ${ }^{60}$ When combined, these two orders are known as a "hybrid order." manual documents that the rationale behind the DOJ's "hybrid" use of these two statutes derives from a combination of discrete statutory requisites. ${ }^{6}$ First, because "cell-site data is 'dialing, routing, addressing or signaling information,' ... 18 U.S.C. \3121(a) requires the government to obtain a Pen/Trap order to acquire this type of information." because CALEA "precludes the government from relying 'solely' on the authority of the Pen/Trap statute to obtain cell-site data for a cell phone ... some additional authority is required to obtain prospective cell-site information." The DOJ asserts that "[s]ection 2703(d) provides this authority because ... it authorizes the government to use a court order to obtain all non-content information pertaining to a customer or subscriber of an electronic communications service [or a remote computing service]." ${ }^{\prime 65}$

The same DOJ manual, published in its third edition in 2009, also provides guidance about the "precision" of the information likely to be obtained from cell site data (exclusive of GPS location technologies). The manual instructs that "[c]ell-site data identifies the antenna tower and, in some cases, the 120-degree face of the tower to which a cell phone is connected, both at the beginning and the end of each call made or received by a cell phone." "The manual further explains that " $[t]$ he towers can be up to 10 or more miles apart in rural areas and may be up to a half-mile or more

60. See id. \2703(c) (authorizing law enforcement to compel "a provider of electronic communications service or remote computing service to disclose a record or other information pertaining to a subscriber to or customer of such service (not including the contents of communications) only when the government entity . . obtains a court order for disclosure under subsection (d) of this section ...”).

61. U.S. DeP’t of Justice (DOJ), SEARChing AND SEIZING Computers AND ObTAINING ELECTRONic EVIDENCE IN CRIMINAL INVESTIGATIONS 160 (3d ed. 2009) [hereinafter DOJ MANUAL], available at http://www.justice.gov/criminal/cybercrime/docs/ ssmanual2009.pdf.

62. Id. at 159-60. Some published decisions also indicate that DOJ prosecutors have, at times, offered the All Writs Act, ch. 646, \1651, 62 Stat. 869, 944 (codified as amended at 28 U.S.C. $\int 1651$ (2010)), as a "mechanism for the judiciary to give [the government] the investigative tools that Congress has not." In re Application of the U.S. for an Order Authorizing the Use of a Pen Register and a Trap and Trace Device (In re E.D.N.Y. Application), 396 F. Supp. 2d 294, 325 (E.D.N.Y 2005); see also In re Application of the U.S. for an Order Authorizing the Installation and Use of a Pen Register (In re W.D.N.Y. Application), 415 F. Supp. 2d 211, 219 (W.D.N.Y 2006). These courts did not endorse this theory.

63. DOJ MANUAL, supra note 61, at 159-60.

64. Id. at 160 .

65. Id.

66. Id. at 159 . 
apart even in urban areas." ${ }^{97}$ Relying on this description of cell tower technology, the manual concludes: "[A]t best, these data reveal the neighborhood in which a cell phone user is located at the time a call starts and at the time it terminates; it does not provide continuous tracking and is not a virtual map of a cell phone user's movements." ${ }^{68}$

This description of the relative precision of cell site data, even if it is intended only to apply to single cell tower data (i.e., no multi-tower, triangulation, or GPS location information), will soon be-if it is not already_outdated with the deployment of microcell, picocell, and femtocell technology that, in some cases, can be more accurate than GPS. ${ }^{69}$ Indeed, in urban areas and other environments where microcell technology is present, a cell phone's location can be identified on an individual floor or room within a building. ${ }^{70}$ Moreover, the precision of single cell tower data will only increase as providers deploy new cell sites to cope with the surge in mobile user data traffic. $^{71}$

The DOJ manual further advises prosecutors that in most districts they may obtain prospective cell site information with the use of hybrid orders, but it also acknowledges that some magistrate judges require a "probable cause" showing before authorizing law enforcement access to any type of prospective cell site data. ${ }^{72}$ This split among magistrate judges, characterized by one federal prosecutor as the "Santa Ana Judicial Revolt," is is discussed next.

\section{Judicial Resistance to the Government's Use of Hybrid Orders}

A growing number of magistrate judges within and across various judicial districts have rejected the government's use of the hybrid theory to obtain any type of prospective cell site information. ${ }^{74}$ Some courts have held that, as

67. Id. (citing In re Application of the United States of America for an Order for Disclosure of Telecomm. Records and Authorizing the Use of a Pen Register and Trap and Trace (In re S.D.N.Y. Application), 405 F. Supp. 2d 435, 449 (S.D.N.Y. 2005)).

68. $I d$.

69. See Location Hearing, supra note 19, at 25 (written statement of Prof. Matt Blaze, Univ. of Pa.).

70. Id.

71. $I d$.

72. DOJ MANUAL, supra note 61, at 159-60.

73. E-mail from Tracy Wilkison re: Changes to GPS / Cell Site for Investigations Form (July 28, 2008) (informing other prosecutors about changes in office procedures for obtaining GPS and cell site information), in U.S. Dep't of Justice, Response to Freedom of Information Act Request No. 07-4123 re: Mobile Phone Tracking 13 (Sept. 8, 2008), available at http://www.aclu.org/pdfs/freespeech/cellfoia_release_074123_20080911.pdf.

74. Location Hearing, supra note 19, at 81-85, 93-94 (testimony of Judge Stephen Wm. Smith, U.S. Magistrate Judge). FED. R. CRIM. P. 41(d)(1) directs that "after receiving an 
a matter of statutory construction, the Pen/Trap order and the D Order cannot be used to obtain prospective cell site information, but that Rule 41 provides the necessary authority because "it governs any matter in which the government seeks judicial authorization to engage in certain investigative activities." 75 More specifically, some of these courts have found that compelled disclosure of prospective cell site data is more akin to a tracking device placed under a vehicle, as defined in 18 U.S.C. $\int 3117,{ }^{76}$ than to the combination of elements comprising the government's hybrid theory and, therefore, would prompt the prudent prosecutor to obtain a Rule 41 warrant. $^{77}$

Even the magistrate and district judges that have accepted hybrid orders and issued published decisions on the question have restricted law enforcement access to limited cell site information "yielding only generalized location data." 78 Magistrate Judge Gorenstein from the Southern District of New York, in what may be the "most cogent expression",79 by a court in accepting the government's hybrid theory, specifically noted:

[The government's request pertained to cell site information] tied only to telephone calls actually made or received by the telephone user ... [with] no data provided as to the location of the cell phone when no call is in progress. [And], at any given moment, data is provided only as to a single cell tower with which the cell phone is communicating. Thus, no data is provided that could be "triangulated" to permit the precise location of the cell phone user. ${ }^{80}$

affidavit or other information," a judge "must issue the warrant if there is probable cause to search for and seize a person or property or to install and use a tracking device."

75. In re E.D.N.Y. Application, 396 F. Supp. 2d 294, 322 (E.D.N.Y 2005); see also In re W.D.N.Y. Application, 415 F. Supp. 2d 211, 219 (W.D.N.Y 2005) ("[T] he challenge here is to the statutory justification for ... [the government's] application. . . The Court does not agree with the government that it should impute to Congress the intent to 'converge' the provisions of the Pen Statute, the SCA, and CALEA to create a vehicle for disclosure of prospective cell information on a real time basis on less than probable cause.").

76. "As used in this section, the term 'tracking device' means an electronic or mechanical device which permits the tracking of the movement of a person or object." 18 U.S.C. \3117(b) (2010).

77. In re Application for Pen Register and Trap/Trace Device with Cell Site Location Authority (In re 2005 S.D. Tex. Application), 396 F. Supp. 2d 747, $753-64$ (S.D. Tex. 2005); In re E.D.N.Y. Application, 396 F. Supp. 2d at 322.

78. Location Hearing, supra note 19, at 93-94 (Exhibit B to written statement of Judge Stephen Wm. Smith) (collecting Magistrate and District Court published decisions where courts have accepted hybrid orders for limited cell site data pertaining to single cell tower and call-related information).

79. Id. at 83 .

80. In re S.D.N.Y. Application, 405 F. Supp. 2d 435, 437-48 (S.D.N.Y 2005). Judge Gorenstein notes differences between the instant case and three published decisions denying 
Judge Gorenstein further explained that his analysis for the instant Order was based on the "technology that is available to the Government in the District," recognizing that, with respect to future cases, "[he could not] know how ... technology may change." ${ }^{81}$

For Judge Gorenstein, then, the current capacity of the cell tower network in question (the court even looked at a map of the location of various cell towers in lower Manhattan-an area it described as "densely populated by cell towers") ${ }^{82}$ was a factor in authorizing law enforcement access to the cell site data with a hybrid order. ${ }^{83}$ If that network's capabilities were to change due to an evolution in technology that yielded more precise location information, the court might rule differently in future cases. Indeed, the court's order might be as ephemeral as the capacities of the specific network the opinion seeks to comprehend at a specific moment in time. Any upgrade to that network that would enhance the accuracy of its geolocation capabilities in the district, made any time after the signing of the opinion, tied as it is to the facts describing the network's capacities, could render that opinion legally moot.

\section{Divergent Interpretations of the Standard for Requiring Disclosure of Prospective Cell Site Data Create Legal Uncertainty}

When seeking to compel "more precise" prospective location data generated by GPS or similar technologies, the DOJ's policy is to obtain a warrant based on probable cause. ${ }^{84}$ While privacy advocates might view this as a small concession by the government, it is at best a transient one, since a policy decision by the DOJ is by no means a permanent or legally binding

government access to cell site information with a hybrid order insofar as " $t$ ]hese cases appear to involve requests for cell site information that go beyond both what has been sought in this case and what has actually been received by the Government pursuant to any cell site application in this District." Id. (citing In re 2005 S.D. Tex. Application, 396 F. Supp. 2d 747; In re E.D.N.Y. Application, 396 F. Supp. 2d 294; In re Application of the U.S. for an Order Authorizing the Installation and Use of a Pen Register and Caller Identification Sys. on Tel. Numbers [Sealed], 402 F. Supp. 2d 597 (D. Md. 2005)).

81. In re S.D.N.Y. Application, 405 F. Supp. $2 \mathrm{~d}$ at 450.

82. Id. at 437.

83. See also In re Application of U.S. for an Order, 411 F. Supp. 2d 678, 680-82 (W.D. La. 2006) (granting an application for cell site information consistent with Judge Gorenstein's reasoning and scope of production of cell site information, recognizing that Judge Gorenstein "limit[ed] his opinion to the particular application before him" and characterizing the single cell site technology of that time as "not permit[ting] detailed tracking of a cell phone user within any residence or building").

84. Senate Judiciary 2011 ECPA Hearing, supra note 7, at 7 (testimony of James A. Baker, Assoc. Deputy Attorney Gen., U.S. Dep't of Justice). 
decision. ${ }^{85}$ To the extent that this policy decision protects privacy, it can be so unstable as to be subject to changes in leadership at various levels, even within a single administration, whose individual decisions implement the enforcement and oversight of a particular policy across various field offices. ${ }^{86}$

More troubling from a systemic perspective, however, is the inconsistent legal landscape that conflicting magistrate and district court decisions create across the country, sometimes even within the same district. ${ }^{87}$ The system neither serves law enforcement needs nor protects privacy interests when legal standards are so uncertain. Moreover, as Judge Gorenstein's opinion illustrates, such uncertainty is magnified into legal instability, potentially to the point of unreliability, when a court's analysis is so tied to the state of

85. A DOJ policy decision, such as a policy requiring a warrant for law enforcement to acquire GPS-generated location data, has no binding authority on state or local law enforcement practices, and state investigators do not always follow DOJ policies. For example, in Devega $v$. State, investigators, without a warrant, requested a defendant's cell phone provider to "ping" his phone, which involved sending a signal to locate it through GPS information. 689 S.E.2d 293, 299 (Ga. 2010).

86. Consider, for example, Magistrate Judge Feldman's exchange with an Assistant United States Attorney ("AUSA") at oral argument. See In re W.D.N.Y. Application, 415 F. Supp. 2d 211, 218 (W.D.N.Y. 2006). While the government was only seeking "general [prospective cell site] location information" in the instant case, the AUSA conceded that in previous "hybrid" applications, the government had sought "prospective cell site data that could be used by law enforcement to triangulate the location of a cell phone to a degree perhaps beyond 'general location information.' "Id. The court pressed government counsel regarding whether the position that a hybrid order was appropriate for anything other than "general location information" had been abandoned. The AUSA responded:

Well there's a couple of practical things going on. One, we're before magistrate judges that are the gatekeepers-we're trying to convince them that the government isn't being some ruthless, overbearing entity-we're trying to be reasonable. So, therefore, if we can get the magistrate's ear and we don't have to fight this fight a zillion times, we'll back off. If you have this internal radar that's going "privacy interest, privacy interest", okay we'll back off. But is it possible the argument could be made that we could be here on another day having gotten to floor one and now we're trying to get to floor two? Yes. Has that been suggested by anyone? Absolutely not.

Id. at 218 n.5; see also Freiwald, supra note 52, at 717 (discussing one U.S. Attorney's Office's failure to comply with DOJ policy advising agents to establish probable cause when seeking location data indicating a target's latitude and longitude (using either GPS or similarly precise data)).

87. See Location Hearing, supra note 19, at 83-85, 93-94 (written statement of Judge Stephen Wm. Smith and Exhibit B thereto). Compare In re an Application of the U.S. for an Order for Prospective Cell Site Location Info. on a Certain Cellular Tel., No. 06 CRIM. MISC. 01, 2006 WL 468300 (S.D.N.Y. 2006) (denying application for limited single tower data), with In re S.D.N.Y. Application, 405 F. Supp. 2d 435 (granting application for limited single tower data). 
technology in a particular district at a particular moment in time that it hinges upon a court's own examination of a network map of cell towers in a particular district-which would now include microcells, picocells, and femtocells - combined with expert opinion on the accuracy of location data that network could produce. ${ }^{88}$ The court analyzed and accepted the government's hybrid theory (while, at the same time, limiting its ruling to the state of the technology available to the government in the district at that time), but it declared the result "unsatisfying" given Congress's lack of clear guidance regarding the appropriate standard for law enforcement access to prospective cell site data. ${ }^{89}$

Even the DOJ has acknowledged the need for legislation to clarify the standard governing compelled disclosures of prospective cell site data. The DOJ, however, carefully limited its recommendation to "cell tower information associated with cell phone calls," which is perhaps the particular area where the DOJ seeks specifically to retain the more nimble and efficient investigative standard provided by the hybrid order, ${ }^{90}$ as opposed to the higher probable cause standard. ${ }^{91}$ In the DOJ's view, "[s]ome courts . . have conflated cell site location information with more precise GPS (or similar) location information" 92 and, as previously noted, they are already advising prosecutors to seek probable cause warrants for "more precise" GPS location data.

With location information-including single cell tower data-becoming only more precise over time and courts continuing to search for an illusory "intended" congressional standard to govern law enforcement access to prospective location data, the search for clarity remains an uncertain one at best in the absence of congressional action.

\section{B. Legal Background for Historical Cell Site Data}

If the uncertainty over what standard to apply to prospective location information has left courts without a strong sense of direction, that

88. See In re W.D.N.Y. Application, 415 F. Supp. 2d at 213 n.3 (reviewing a letter from Verizon's Court Order Compliance Manager "which states that the information sought will only 'identify the general area that the target mobile phone located at the time of a specific call' and that it 'cannot pinpoint the exact location of the mobile phone" ").

89. In re S.D.N.Y. Application, 405 F. Supp. $2 \mathrm{~d}$ at 442.

90. Senate Judiciary 2011 ECPA Hearing, supra note 7, at 5 (testimony of James A. Baker).

91. Mr. Baker explains earlier in his congressional testimony that "if an amendment were unduly to restrict the ability of law enforcement to quickly and efficiently determine the general location of a terrorist, kidnapper, child predator, computer hacker, or other dangerous criminal, it would have a very real and very human cost." Id. at 6.

92. Mr. Baker's testimony does not cite to specific examples where the DOJ believes courts have conflated cell site information with more GPS location information. See id. at 7 . 
confusion is becoming even more pervasive with regard to historical cell site data. Lower courts are now beginning to split over the proper access standard to apply to it as well. In this context, as with prospective cell site location data, 18 U.S.C. $\int 2703$ (c) permits the government to compel "a provider of electronic communications service or remote computing service to disclose a record or other information pertaining to a subscriber to or customer of such service (not including the contents of communications) only when the government entity ... obtains a court order for disclosure under subsection (d) of this section." "93 Stated more simply, a D Order "compels [production of] all non-content records." 94

\section{The DOJ's Interpretation of the Standard for Obtaining Historical Cell Site Data}

The DOJ takes the position that historical cell site information satisfies each of the three elements necessary to fall within the scope of 18 U.S.C. \2703. ${ }^{95}$ First, a cell phone company is a provider of "electronic communications service" to the public. "Second, "cell site information constitutes 'a record of other information pertaining to a subscriber or to a customer of such service (not including the contents of communications)." "97 More specifically, historical cell site information "is a record stored by the provider concerning the particular cell tower used by a subscriber to make a particular cell phone call, and is therefore 'a record or

93. 18 U.S.C. \ 2703 (c) (2010).

94. Orin S. Kerr, A User's Guide to the Stored Communications Act, and a Legislator's Guide to Amending It, 72 GEO. WASH. L. REV. 1208, 1222 (2004).

95. Brief for the United States at 8-9, In re the Application of the U.S. for an Order Directing a Provider of Elec. Commc'n Serv. To Disclose Records to the Gov't (Appeal of In re W.D. Pa. Application), 620 F.3d 304 (3d Cir. 2010) (No. 08-4227), 2009 WL 3866618.

96. Id. at 10. The Wiretap Act and SCA define electronic communication service ("ECS") to mean "any service which provides to users thereof the ability to send or receive wire or electronic communications." 18 U.S.C. \$S 2510(15), 2711(1). Cell phone service providers provide their customers with the ability to send "wire communications," and thus they are providers of electronic communications service. See $\int 2510(1)$, (15). Moreover, the DOJ takes the position that:

[a] "wire communication" necessarily involves the human voice. See \2510(1) (defining "wire communication") and \ 2510 (defining "aural transfer"); S. Rep. No. 541, 99th Cong., 2d Sess. 11 (1986), reprinted in 1986 U.S. Code Cong. \& Admin. News 3555, 3565 ("cellular communications-whether they are between two cellular telephones or between a cellular telephone and a 'land line' telephone-are included in the definition of 'wire communications' and are covered by the statute").

Brief for the United States, supra note 95, at 11 n.10.

97. Brief for the United States, supra note 95, at 11. 
other information pertaining to a subscriber or customer.' "98 Finally, "cell site information is non-content information, as it does not provide the content of any phone conversation the user has had over the cell phone." 99 Based on this analysis, prosecutors and agents regularly use D Orders to compel historical location information from third-party providers.

\section{Judicial Interpretation of the Standard for Obtaining Historical Cell Site Data}

Lower courts have, for the most part, accepted the government's use of a D Order to compel historical cell site information. ${ }^{100}$ However, one circuit court has held that there may be circumstances in which a judge can require a probable cause showing before authorizing a government-compelled disclosure of historical cell site information.

a) The Third Circuit Finds That Magistrate Judges Have the Discretion To Require Probable Cause

A government appeal of a magistrate judge's opinion ${ }^{101}$ denying the use of a D Order to compel historical cell site data led the Third Circuit to consider whether a D Order based on "specific and articulable facts" can be sufficient to allow the government to compel the production of historical cell site data and whether, in some cases, a court should apply the Fourth Amendment's probable cause requirement in place of the more relaxed provisions of the SCA governing the disclosure of historical cell site information. ${ }^{102}$ The Third Circuit held that historical cell site data "is obtainable under a $\int 2703$ (d) order and that such an order does not require

98. Id. (citing In re S.D.N.Y. Application, 405 F. Supp. 2d 435, 444 (S.D.N.Y 2005), and noting that cell site data is "information" and " "pertain[s]' to a subscriber or customer of cellular telephone service").

99. Id. (citing 18 U.S.C. $\int 2510(8)$ and defining the "contents" of communications to include information concerning its "substance, purport, or meaning").

100. See In re Applications of the U.S. for Orders Pursuant to Title 18, U.S. Code, Section 2703(d), 509 F. Supp. 2d 76, 82 (D. Mass. 2007) (granting the government's application for historical cell site information based on the government's statutory analysis of 18 U.S.C. $\left.\iint 2703(\mathrm{c}),(\mathrm{d})\right) ; i d$. at $79 \mathrm{n} .5$ (collecting cases where courts have assumed or applied in dicta that compelling disclosure of historical cell site data is proper under $\int 2703$ (d) of the SCA).

101. In re Application of the U.S. for an Order Directing a Provider of Elec. Commc'n Serv. To Disclose Records to the Gov't (In re W.D. Pa. Application), 534 F. Supp. 2d 585 (W.D. Pa. 2008). On appeal from the Magistrate Judge to the District Court, the court "recognized 'the important and complex matters presented in this case,' but affirmed in a two page order without analysis." Appeal of In re W.D. Pa. Application, 620 F.3d 304 (3d Cir. 2010) (citing In re W.D. Pa. Application, 534 F. Supp. 2d 585).

102. Appeal of In re W.D. Pa. Application, 620 F.3d 304. 
the traditional probable cause determination."103 The Third Circuit also found, however, that magistrate judges have the discretion to turn down a government application for a D Order even when the D Order standard has been satisfied and, instead, require a probable cause showing. This determination is based upon the Third Circuit's reading of D Order statutory language as "language of permission rather than mandate." 104 The extent to which a magistrate judge has discretion to deny a D Order is unclear, as the opinion merely instructs that the option to require a warrant "be used sparingly because Congress also included the option of a $\ 2703$ (d) order," that judges do not have "arbitrary" discretion, and in those cases where a magistrate judge does require a warrant, she must "make fact findings and give a full explanation that balances the government's need (not merely desire) for the information with the privacy interests of cell phone users."

In his concurring opinion, Judge Tashima noted his agreement with most of the reasoning of the majority opinion, but he was concerned that "contradictory signals" leave magistrate judges and prosecutors with a lack of "standards by which to judge whether an application for a $\int 2703$ (d) order is or is not legally sufficient."106 Judge Tashima explained that "the majority suggests that Congress did not intend to circumscribe a magistrate's discretion in determining whether or not to issue a court order, while at the same time, acknowledging that [o]rders of a magistrate judge must be supported by reasons that are consistent with the standard applicable under the statute[.]" "107 Contrary to the majority's statement that "a magistrate judge does not have arbitrary discretion," Judge Tashima suggests that the majority's opinion perpetuates exactly that, because:

it provides no standards for the approval or disapproval of an application for an order under $\$ 2703(\mathrm{~d}) \ldots$ [and it] vests magistrate judges with arbitrary and uncabined discretion to grant

103. Id. at 313 .

104. Id. at 316 ("We begin with the text. Section 2703(d) states that a "court order for disclosure under subsection (b) or (c) may be issued by any court that is a court of competent jurisdiction and shall issue only if' the intermediate standard is met. 18 U.S.C. $\int 2703$ (d) (emphasis added). We focus first on the language that an order 'may be issued' if the appropriate standard is met. This is the language of permission, rather than mandate. If Congress wished that courts 'shall,' rather than 'may,' issue \2703(d) orders whenever the intermediate standard is met, Congress could easily have said so. At the very least, the use of 'may issue' strongly implies court discretion, an implication bolstered by the subsequent use of the phrase 'only if' in the same sentence.").

105. Id. at 316, 319.

106. Id. at 320 (Tashima, J., concurring).

107. Id. 
or deny issuance of $\int 2703(\mathrm{~d})$ orders at the whim of the magistrate, even when the conditions of the statute are met. ${ }^{108}$

Indeed, the very instability that currently plagues the prospective cell site data legal landscape might also "fester" with respect to historical access standards if the Third Circuit's "rule," giving magistrate judges discretion to deny a D Order without standards or guidance about when such denial is appropriate, were to become the law of the land. ${ }^{109}$

In the wake of the Third Circuit's opinion, some magistrate judges who once granted access to historical cell site data with a D Order are now revisiting that practice. In Magistrate Judge Smith's recent opinion, however, the court placed more significance on "new technology" that has "altered the legal landscape even more profoundly than the new caselaw." "110 Judge Smith's opinion meticulously documents the changes in technology leading to his determination that "court decisions allowing the Government to compel cell site data without a probable cause warrant were based on yesteryear's assumption that cell site data (especially from a single tower) could locate users only imprecisely." 111 After establishing the state of current technology and its rapid pace of change in the direction of increased accuracy for the factual record, Judge Smith conducted a constitutional analysis and ultimately concluded that a compelled warrantless disclosure of sixty days of historical cell site data violates the Fourth Amendment. ${ }^{112}$

b) The D.C. Circuit's "Mosaic Theory"

Prior to Judge Smith's opinion, Magistrate Judge Orenstein, another judge who previously granted requests for historical cell site data pursuant to a D Order, also denied the government's application absent a warrant based

108. Id.

109. For a more extended analysis and critique of the Third Circuit opinion, see Orin S. Kerr, Third Circuit Rules That Magistrate Judges Have Discretion To Reject Non-warrant Court Order Applications and Require Search Warrants To Obtain Historical Cell Site Records, VOLOKH CONSPIRACY (Sept. 8, 2010), http://volokh.com/2010/09/08/third-circuit-rules-thatmagistrate-judges-have-discretion-to-reject-court-order-application-and-require-search-war rants-to-obtain-historical-cell-site-records/.

110. In re Application of the U.S. for Historical Cell Site Data (In re 2010 S.D. Tex. Application), 747 F. Supp. 2d 827 (S.D. Tex. 2010).

111. Id. at 830 .

112. The court's reasoning can be summarized as follows: (1) under current location technology, cell site information reveals non-public information about constitutionally protected spaces; (2) historical cell site records are subject to Fourth Amendment protection under the prolonged surveillance doctrine of United States v. Maynard, 615 F.2d 544 (D.C. Cir. 2010); and (3) the government has not demonstrated that the location data sought was voluntarily conveyed by the user and therefore Smith v. Maryland, 442 U.S. 735 (1979), does not eliminate a legitimate expectation of privacy. 
on a probable cause showing. ${ }^{113}$ In finding the government's D Order application for historical cell site data over a fifty-eight-day period to be an unreasonable search and seizure under the Fourth Amendment, ${ }^{114}$ Judge Orenstein's opinion relies heavily on a recent D.C. Circuit Fourth Amendment decision, United States v. Maynard. ${ }^{115}$ The court in Maynard considered whether the government's warrantless use of a GPS device placed on a vehicle to track a suspect's movements for twenty-eight days, twentyfour hours a day, was an unreasonable search under the Fourth Amendment. In concluding that the long-term GPS surveillance of movements exposed to public view was a search, ${ }^{116}$ the Maynard court recognized a novel "mosaic theory" of the Fourth Amendment. ${ }^{117}$ Specifically, the court explained:

Prolonged surveillance reveals types of information not revealed by short term surveillance ... [and] can reveal more about a person than does any individual trip viewed in isolation .... A person who knows all of another's travels can deduce he is a weekly church goer, a heavy drinker, a regular at the gym, an unfaithful husband, an outpatient receiving medical treatment, an associate of particular individuals or political groups — and not just one such fact about a person, but all such facts. ${ }^{118}$

As Professor Orin S. Kerr observes, under the mosaic theory, a court determines whether government conduct is a search "not by whether a particular individual act is a search, but rather whether an entire course of conduct, viewed collectively, amounts to a search." "119 Individual acts that

113. In re Application of the U.S. for an Order Authorizing Release of Historical CellSite Info. (In re 2010 E.D.N.Y. Application), 736 F. Supp. 2 d 578 (E.D.N.Y 2010). But see In re Application of the U.S. for an Order Authorizing Disclosure of Historical Cell Site Info. for Tel. No. [redacted], Misc. No. 11-449, at 5 (D.D.C. Oct. 3, 2011) (Lamberth, C.J.), available at http://legaltimes.typepad.com/files/lamberth_ruling.pdf (holding that a D Order permits the government to compel disclosure of historical location data without a probable cause search warrant and that Maynard does not control the question).

114. In re 2010 E.D.N.Y. Application, 736 F. Supp. 2 d at 582.

115. United States v. Maynard, 615 F.3d 544 (D.C. Cir. 2010), reh'g denied sub nom. United States v. Jones, 625 F.3d 766 (D.C. Cir. 2010), aff'd, 132 S. Ct. 945 (2012).

116. In reaching its decision, the court explained how the reasoning of Knotts did not foreclose the conclusion that long-term surveillance constitutes a search. Maynard, 615 F.3d at 556-58. Indeed, the Court interpreted the Knotts opinion as reserving the question of whether prolonged use of a beeper device would require a warrant. Id. at 556. The court acknowledged, however, that appellate courts in three other circuits have reached opposite conclusions under Knotts. Id. at 557-58.

117. Id. at 562 .

118. Id. (footnote omitted).

119. See Orin S. Kerr, D.C. Circuit Introduces "Mosaic Theory" of Fourth Amendment, Holds GPS Monitoring a Fourth Amendment Search, VOLOKH CONSPIRACY (Aug. 6, 2010), http:// 
may not, in their own right, be searches can become searches when committed in particular combinations. ${ }^{120}$ Thus in Maynard, the court does not look at individual data recordings from the GPS device to determine whether, for example, individual trips are searches. ${ }^{121}$ Instead, "the Court examines the entirety of surveillance over a one-month period and views it as one single 'thing'" subject to Fourth Amendment analysis. ${ }^{122}$ But at what point would a single act or a series of acts amount to the prolonged surveillance that triggers the mosaic theory and how does a prosecutor, judge, or defense attorney recognize the phenomenon? The Maynard court gives no real guidance in this regard. ${ }^{123}$ Indeed, the Solicitor General in the government's brief filed in Jones (formerly Maynard) ${ }^{124}$ has argued: "[T]he 'mosaic' theory is unworkable. Law enforcement officers could not predict when their observations of public movements would yield a larger pattern and convert legitimate short-term surveillance into a search. Courts would be hard pressed to pinpoint that moment even in retrospect." 125

While acknowledging primary factual differences between the real-time GPS vehicle tracking in Maynard and the government's application for two months' worth of historical cell site data, Judge Orenstein finds the Maynard opinion "persuasive" support for his analysis that the Fourth Amendment

volokh.com/2010/08/06/d-c-circuit-introduces-mosaic-theory-of-fourth-amendmentholds-gps-monitoring-a-fourth-amendment-search/.

120. Id.

121. Id.

122. Id.

123. In United States v. Cuevas-Perez, 640 F.3d 272 (7th Cir. 2011), the Seventh Circuit considered whether Maynard applied to a 60-hour, "factually straightforward" warrantless GPS surveillance. Id. at 274. In determining that Maynard did not apply to the case, the majority opinion reasoned that Maynard's 28-day surveillance was much lengthier than the 60-hour surveillance before the Seventh Circuit and the "single trip" in the instant case did not "expose or risk exposing" the "twists and turns" of the defendant's life, "including possible criminal activities, for a long period." Id. at 274. In concluding Maynard did not apply, however, the majority emphasized "the present case . . is not meant to approve or disapprove the result the D.C. Circuit reached under the facts of that case." Id. at 274 n.3. The concurring and dissenting opinions in Cuevas-Perez do provide some analysis of Maynard. Indeed, the concurring opinion generally finds Maynard's mosaic theory "unworkable," with Judge Flaum indicating that it is not "obvious" to him where the Maynard Court would "draw constitutional lines around Cuevas-Perez's sixty-hour journey." Id. at 282. In contrast, Judge Wood's dissent rejects the majority's "single trip" description, finding much more similarity between Cuevas-Perez's "60 hour odyssey across 1,650 miles" and the prolonged surveillance in Maynard. Id. at 293.

124. See supra note 115 .

125. Brief for the United States at 14, United States v. Jones, 132 S. Ct. 945 (2012) (No. 10-1259), 2011 WL 3561881. Indeed, Respondent Jones does not employ the Maynard "mosaic theory" in his brief to the Supreme Court. See Brief for Respondent Antoine Jones at 45, Jones, 132 S. Ct. 945 (2012) (No. 10-1259), 2011 WL 4479076. 
requires the government to obtain a warrant to compel the location information. ${ }^{126}$ Lower courts' reliance on Maynard's "mosaic theory," however, raises questions, once again, about the viability of a series of cases that give prosecutors and judges little to no guidance about when and what amount of location data is subject to Fourth Amendment protection. Judge Orenstein, for example, found that fifty-eight days of historical cell site data required a warrant under the reasoning in Maynard but, in a later opinion applying Maynard, he granted an application for discreet amounts of data spanning a twenty-one-day period under a D Order. ${ }^{127}$ While such opinions may be heralded as a "victory" for privacy interests because, among other things, they have the effect of destabilizing the government's use of the D Order, they serve neither privacy nor law enforcement interests insofar as they perpetuate a legal landscape in which lower courts continue to "search," in vain, for the appropriate standards to apply.

\section{The Jones Decision}

Notwithstanding such criticism of the mosaic theory in Maynard, the concurring opinions in United States $v$. Jones ${ }^{128}$ suggest that, in some future case, there may be five votes for a mosaic-type Fourth Amendment theory holding that "the use of longer term GPS monitoring in investigations of most offenses impinges on expectations of privacy." ${ }^{129}$ Indeed, Justice Alito's

126. In re 2010 E.D.N.Y. Application, 736 F. Supp. 2d 578, 584 (E.D.N.Y. 2010). This Article does not focus on appropriate standards for law enforcement use of GPS tracking devices installed on vehicles - which do not involve compelled disclosures from third-party ECPA-covered providers - and which, therefore, as a matter of policy, may implicate slightly different equities and interests for Congress to consider when drafting legislation.

127. In re Application of the U.S. for an Order Authorizing Release of Historical CellSite Info., No. 11-MC-0113, 2011 WL 679925 (E.D.N.Y. 2011). The government's application for historical cell site data sought information from one phone for a three-day period, a six-day period from the same phone commencing less than a month later, and a twelve-day period from a second phone believed to have been used in furtherance of the offenses under investigation. $I d$. at $* 1$. The court distinguished the result of the instant case from that of Maynard primarily because the court could not "assume that the information gleaned over such shorter periods, separated by breaks of weeks or months, would necessarily be as revealing as the sustained month-long monitoring at issue in Maynard." Id. at *2. In making this distinction, however, the court acknowledged that "any such line drawing is, at least to some extent, arbitrary and the need for such arbitrariness arguably undermines the persuasiveness of Maynard, and of [this court's] prior decisions." Id. For further analysis and critique of this decision, see Orin S. Kerr, Applying the Mosaic Theory of the Fourth Amendment to Disclosure of Stored Records, VOLOKH CONSPIRACY (Apr. 5, 2011), http://volokh. com/2011/04/05/applying-the-mosaic-theory-of-the-fourth-amendment-to-disclosure-ofstored-records/.

128. 132 S. Ct. 945 (2012).

129. Id. at 964 (Alito, J., concurring). Justices Ginsburg, Breyer, and Kagan joined Justice Alito's concurrence. While Justice Sotomayor did not join the Alito concurrence, she states 
concurrence invokes the novel aggregative Fourth Amendment theory first articulated by the D.C. Circuit in Maynard. The Alito concurrence posits that "relatively short-term monitoring of a person's movements on public streets accords with expectations of privacy that our society has recognized as reasonable" while law enforcement's "secretly monitor[ing] and catalogu[ing] every single movement of an individual's car for a very long period" does not accord with reasonable expectations of privacy. ${ }^{130}$ Likewise, Maynard previously recognized that " $[\mathrm{p}]$ rolonged surveillance reveals types of information not revealed by short term surveillance."131

While Justice Alito's concurrence applies the Katr.132 "expectation-of privacy test," the majority opinion, authored by Justice Scalia, bases its holding partially on a trespass theory: "We hold that the Government's installation of a GPS device on a target's vehicle, and its use of that device to monitor the vehicle's movements, constitutes a 'search." "133 Justice Scalia defines the offending conduct further stating "the Government physically occupied private property for the purpose of obtaining information." Consequently, though "[t]respass alone does not qualify [as a search]," a search does occur when it is "conjoined" with "an attempt to find something or to obtain information." 135

Justice Alito criticizes this approach because, among other things, it "largely disregards what is really important (the use of a GPS for long-term tracking) and instead attaches great significance to something that most would view as relatively minor (attaching to the bottom of a car a small, light object that does not interfere in any way with the car's operation)." 136 Indeed, the attachment-focused majority opinion does not address instances where the use of GPS solely involves the transmission of radio or other electronic

in her own concurrence, "I agree with Justice ALITO that, at the very least, 'longer term GPS monitoring in investigations of most offenses impinges on expectations of privacy.' " $I d$. at 955 (Sotomayor, J., concurring). See also Orin S. Kerr, What's the Status of the Mosaic Theory After Jones?, VOLOKH CONSPIRACY (Jan. 23, 2012), http://volokh.com/2012/01/23/whatsthe-status-of-the-mosaic-theory-after-jones/ (explaining that the mosaic theory "lives").

130. Jones, 132 S. Ct. at 964 (Alito, J., concurring).

131. United States v. Maynard, 615 F.3d 544, 562 (D.C. Cir. 2010), reh'g denied sub nom. United States v. Jones, 625 F.3d 766 (D.C. Cir. 2010), aff'd, 132 S. Ct. 945 (2012).

132. Katz v. United States, 389 U.S. 347 (1967). “As Justice Harlan's oft-quoted concurrence described it, a Fourth Amendment search occurs when the government violates a subjective expectation of privacy that society recognizes as reasonable." Kyllo v. United States, 533 U.S. 27, 33 (2001) (citing Katz, 389 U.S. at 361).

133. Jones, 132 S. Ct. 945.

134. Id.

135. Id. at 951 n. 5 .

136. Id. at 961 (Alito, J., concurring). 
signals not enabled by the government's direct physical trespass-such as tracking a target's cell phone. ${ }^{137}$ While acknowledging that government tracking though electronic means without actual physical trespass may be "an unconstitutional invasion of privacy," the majority opinion asserts "the present case does not require us to answer that question." 138 Moreover, the majority opinion criticizes the line-drawing problems the Alito concurrence presents:

[I]t remains unexplained why a 4-week investigation is "surely" too long and why a drug-trafficking conspiracy involving substantial amounts of cash and narcotics is not an "extraordinary offens[e]" which may permit longer observation. What of a 2-day monitoring of a suspected purveyor of stolen electronics? Or of a 6-month monitoring of a suspected terrorist? ${ }^{139}$

Indeed, consistent with the difficulties Maynard raised, Justice Alito's adoption of a mosaic-type theory provides no significant guidance to law enforcement, judges, and industry about when Fourth Amendment concerns materialize: "We need not identify with precision the point at which the tracking of this vehicle became a search, for the line was surely crossed before the 4-week mark." ${ }^{, 140}$ Rather than creating clarity in the law, the Alito concurrence perpetuates, perhaps even intensifies, the confusion surrounding appropriate law enforcement standards for access to location data.

\section{The Importance of Legislative Clarity in the Face of Rapid Technological Change}

Scholars and advocates may legitimately disagree about Fourth Amendment theory and about courts' application of the Fourth Amendment to government-compelled disclosures of cell site data. Notwithstanding this constitutional debate, however, the current pace of technological change in this area has given rise to inordinately difficult analytical challenges and highlighted a consequent need for Congress to clarify or amend the law. Chief among these challenges is the current instability in the law created when courts must struggle to find congressional intent in laws that predate the current state of location technology-in short, to find intention in the absence of a stable object. In the face of this ultimately futile search for historical interpretive authority, courts must grapple directly with the legal

137. Id. at 953 ("Situations involving merely the transmission of electronic signals without trespass would remain subject to the Katz analysis.").

138. Id.

139. Id. (citation omitted).

140. Id. at 964 (Alito, J., concurring). 
implications that enormously complex and quickly evolving location technologies raise in conjunction with the facts of a given case. Finally, courts must try to perform the foregoing analysis while simultaneously confronting any implications the rapid rate of change in the capabilities of location technology might have upon the reasonable scope of their decisions. To avoid these difficult acts of legal navigation, policymakers should enact laws containing clear standards that strike the right balance among law enforcement needs and privacy and industry interests. These standards must also be flexible enough to accommodate the pace of technological change to a degree that renders it a moot consideration in any court's analysis.

\section{Questions Raised by the Two Existing Standards FOR COMPELLING Disclosure OF LOCATION DATA}

\section{What Does a "D" Order Require the Government To Show?}

The call by some advocates for a probable cause standard to govern all law enforcement compelled disclosures of location data is, of course, a recognition that the $\mathrm{D}$ Order affords a less stringent showing by law enforcement than that required to meet probable cause. ${ }^{141}$ Specifically, to obtain a D Order, law enforcement must provide "specific and articulable facts that there are reasonable grounds to believe" that the information to be compelled "is relevant and material to an ongoing investigation." " Some scholars have referred to the D Order standard as a "Terry-stop" standard, a reference to Terry $v$. Obio, where the Supreme Court created the reasonable suspicion standard for sidewalk stop-and-frisk encounters. ${ }^{143}$ The Terry standard is met "when an officer "point[s] to specific and articulable facts which, taken together with rational inferences from those facts, evince more

141. See H.R. REP. NO. 103-837, at 31 (1994) (indicating that the D Order is "an intermediate standard ... higher than a subpoena, but not a probable cause warrant").

142. 18 U.S.C. \ 2703(d) (2010).

143. 392 U.S. 1, 30 (1968); see also Christopher Slobogin, Privacy at Risk: The New Government Surveillance And the Fourth Amendment 175-76 (2007) (arguing that the D Order standard, although perhaps intended to be more demanding than the relevance standard required for a subpoena, may not be much different: "[e]ven if material is meant to augment relevant, it does not add much; materiality, in evidence law, means merely that the evidence be logically related to a proposition in the case"); Freiwald, supra note 52, at 692 (discussing that the D Order standard permits much broader inquiries into a much wider range of targets than the probable cause standard); Paul Ohm, Probably Probable Cause: The Diminishing Importance of Justification Standards, 54 MINN. L. REV. 1514, 1521-22 (2010) (noting that the D Order standard "is probably much more stringent than the mere-relevance subpoena standard" and is set by Congress "at a high enough level to prevent police fishing expeditions"). 
than an inchoate and unparticularized suspicion or hunch of criminal activity.' ",144

From a practical standpoint, the D Order standard facilitates law enforcement access to non-content records at the early stages of an investigation, when the government is unlikely to meet the higher probable cause standard. In a recent case not involving location information, the DOJ asserted that the D Order standard "derives from the Supreme Court's decision in Terry" and thus "is no more onerous than the Terry rule." "145 As such, the word "material" in 18 U.S.C. \2703(d) "does not transform the $\int 2703(\mathrm{~d})$ standard into one that requires a showing that the records sought are 'vital,' 'highly relevant,' or 'essential.' "146 Indeed, the scope of a D Order may be "appropriate even if it compels disclosure of some unhelpful information," as " " 2703 (d) is routinely used to compel disclosure of records, only some of which are later determined to be essential to the government's case." "147 For example, if investigators compel location information for every cell phone in the vicinity of a murder scene for a specific period of time, they are likely to obtain irrelevant location information about innocent people who just happened to be in a particular place at a particular time in addition to information about the presence of the murderer or witnesses who might have seen the murderer.

Broadening the scope of a request for location information beyond, but in relation to, a known target can advance an investigation strategically. Law enforcement, in certain circumstances, might request the location information of all individuals who were called by or made calls to a particular target. ${ }^{148}$ This practice, sometimes referred to as a "community of interest" request, is of particular concern to privacy advocates, ${ }^{149}$ but it can, for

144. United States v. Mason, 628 F.3d 123, 128 (4th Cir. 2010) (quoting United States v. Branch, 537 F.3d 328, 336 (4th Cir. 2008)).

145. Government's Response to Objections of Three Twitter Subscribers to Magistrate Judge's March 11, 2011 Opinion Denying Motion To Vacate and Denying in Part Motion To Unseal at 8-9, In re Application of the U.S. for an Order Pursuant to 18 U.S.C. $\int$ 2703(d), 2011 WL 5508991 (E.D. Va. 2011) (Misc. Nos. 1:11-DM-3, 10-GJ-3793 \& 1:11-EC-3), available at http:/ / files.cloudprivacy.net/goverment_opp.pdf.

146. Id. at 8-9 (quoting Subscribers' Objections).

147. Id. at 8 (quoting Magistrate Judge Buchanan's Opinion and Order of March 11, 2011).

148. See House Judiciary 2010 ECPA Reform Hearing, supra note 18, at 29-30 (written statement of Albert Gidari, Perkins Coie LLP) (explaining that with respect to location information of specific users, many orders now require disclosure of the location of all of the associates who were called by or made calls to a target).

149. Some privacy scholars express strong concerns with a standard that "allows the government to seek location information about apparently innocent parties regularly," noting that community of interest requests provide law enforcement with information about 
example, enable law enforcement to identify unknown suspects potentially involved in criminal activity with a known target. ${ }^{150}$

Law enforcement often needs the ability to cast a wider investigative net at early stages of an investigation and, assuming the government's interpretation is correct, the D Order standard facilitates this "overcollection" of information. But insofar as the D Order standard does facilitate an often necessary over-collection of information, to what extent does it adequately prevent unnecessary over-collection of information? In other words, should not the D Order standard explicitly require that a sufficient nexus exist between the scope of the location information requested and the criminal activity being investigated?

If so, how should this nexus standard be examined by courts? Determining whether an application reflects a time period tailored to the criminal activity being investigated is one inquiry for courts to make in an effort to legitimately cabin the amount of information collected. A single

individuals only tenuously connected to a crime without the judicial oversight that a warrant guarantees. See Freiwald, supra note 52, at 718.

150. Consider the following scenario: British authorities at an airport package transit $\mathrm{x}-$ ray station in Coventry, England x-rayed a package and discovered a .375 Magnum revolver hidden inside a child's toy boat. More packages containing weapons and ammunition concealed inside children's toys were also discovered. When the revolver from the first package was removed, agents noticed that the gun's serial number had been filed down, but forensic analysis reconstructed the number, allowing law enforcement to trace the gun back to a dealer with a known identity and a female gun purchaser with a known identity in South Florida. The packages had also been mailed from South Florida via express mail, which allowed agents to identify the location, time, and date that the package was mailed. Cameras inside those post offices recorded video showing two men mailing the first package containing the .357 Magnum revolver. No further information identifying those men was known at the time. It is reasonable to assume that the woman who purchased the revolver (whose identity law enforcement had confirmed) called or was called by the men who mailed the package. One way to assist law enforcement in identifying the men (who continued to mail packages ultimately discovered at Coventry airport) would be to obtain location information focused on the individuals in contact with the known female gun purchaser.

This factual scenario is taken from a real case, United States v. Claxton, No. 99-06176 (S.D. Fla. June 13, 2000) (Ferguson, J.), prosecuted by Stephanie in 1999-2000 involving a cell of IRA operatives who came to the United States, purchased weapons illegally, hid them in children's toys and large, hollowed-out computer towers, and mailed them to the Republic of Ireland where they would be smuggled into Belfast. This operation was occurring during a critical time in the peace process and the weapons were intended to replace the cache of weapons being turned over as part of the Good Friday Agreements. The factual narrative described is condensed to illustrate how a "community of interest" request would have assisted in identifying the identities of the men mailing the packages, had such a practice been in use at that time. For more information about the case, see Mike Clary, Lax Florida Laws Attracted IRA, REGISTER-GUARD (Eugene, Or.), June 8, 2000, at 6A, available at http:/ / goo.gl/S6BgC. 
bank robbery occurring over the course of an hour committed by a few suspects, for example, would likely require a narrower collection of information than a sophisticated drug conspiracy covering multiple jurisdictions with multiple conspirators occupying different roles and performing different tasks. Not only would the length of time reflected in the bank robbery D Order application likely be shorter than in the drug conspiracy application, but the number of individuals targeted (known and unknown) might also be fewer. In certain types of investigations, identities of targets are not initially known, but locations where crimes or activities relevant to determining the identities of suspects are known. When the request for the location data is centered on a place where an activity occurred, courts can ensure that the length of the request (i.e., from "Time $X$ " to "Time $Y$ ") is sufficiently tailored to when the investigation suggests that the suspects were present at the location. Similarly, when community of interest requests are made, courts could ensure that the breadth of location information requested about individuals who called or were called by a target is reasonable in light of investigative facts described in the application. There are, of course, many permutations of how the scope of a request for location data would manifest in a particular investigation. Considering that D Orders necessarily facilitate an over-collection of information, however, Congress could amend the language of $\ 2703$ (d) to ensure that courts are examining whether a sufficient nexus exists between the scope of the location information requested and the criminal activity being investigated.

\section{Probable Cause of What?}

A strict probable cause standard for the disclosure of location information could interfere with legitimate law enforcement objectives. Some of the privacy concerns motivating the advocacy for the application of a probable cause standard to all law enforcement compelled disclosures of any and all location information are discussed later in Part V. At this stage in the analysis, however, it is useful to explore how a strict definitional application of the probable cause standard—as articulated in Rule $41^{151}$ — might unduly limit some of the basic law enforcement uses of prospective and historical location information to the degree that legitimate investigative activities

151. See FED. R. CRIM. P. 41(c) (listing categories of probable cause: "(1) evidence of a crime; (2) contraband, fruits of crime, or other items illegally possessed; (3) property designed for use, intended for use, or used in committing a crime; or (4) a person to be arrested or a person who is unlawfully restrained"). 
dependent upon the use of these tools would be inhibited, even thwarted, from the start. ${ }^{152}$

If required to obtain a Rule 41 warrant for compelled disclosures of location information, the government would need to establish probable cause to believe that the location information itself is evidence of a crime. ${ }^{153}$ In some instances, the location of a cell phone, insofar as it reveals a suspect's location, would qualify as evidence of a crime. Location information, for example, may rebut a defendant's alibi, place a defendant at the scene of a crime, or show that a defendant's movements are consistent with activities or overt acts alleged in furtherance of a criminal conspiracy.

But not every use of location information by law enforcement easily fits into the "evidence of a crime" element of Rule 41. If, for example, a person has committed a crime in the past, her current location may not be evidence of a crime, yet there might exist circumstances in which law enforcement has a legitimate need to find her. ${ }^{154}$ If law enforcement has evidence to suggest that a person is about to commit a crime, her current location or prospective location leading up to the commission of that crime may or may not, itself, be evidence of a crime, yet our society generally accepts that law enforcement has a legitimate need to prevent her from committing a crime. Indeed, when addressing the DDP proposal that a probable cause warrant should be required for law enforcement access to all location data, Professor Kerr posed the question, "probable cause of what?"155 Is it "probable cause to believe the person tracked is guilty of a crime" or "probable cause to believe the evidence of location information obtained would itself be evidence of a crime?" 156 Professor Kerr noted that the difference is important because, in the case of a search warrant, probable cause generally refers to probable

152. We do not claim to know, nor are we able to anticipate, all of the ways in which law enforcement uses prospective and historical location information in investigations.

153. See In re Application of the U.S. for an Order Authorizing the Release of Prospective Cell Site Info., 407 F. Supp. 2d 134, 135 (D.D.C. 2006) (explaining the difference between the $\mathrm{D}$ Order standard and probable cause as being that the latter requires a finding that there is probable cause to believe that the information sought is itself evidence of a crime rather than reasonable grounds to believe that the information sought is relevant and material to an ongoing investigation).

154. Some courts, however, have construed the probable cause requirement more broadly with respect to tracking devices or cell site data. See, e.g., In re Application of the United States for and [sic] Order: (1) Authorizing the Use of a Pen Register and Trap and Trace Device; (2) Authorizing Release of Subscriber and Other Info.; and (3) Authorizing the Disclosure of Location-Based Servs., 727 F. Supp. 2d 571, 581-82 (W.D. Tex. 2010).

155. House Judiciary 2010 ECPA Reform Hearing, supra note 18, at 39 (written statement of Prof. Orin S. Kerr, The George Washington Univ. Law Sch.).

156. Id. 
cause to believe that the information sought is itself evidence of a crime. ${ }^{157}$ Cell phone location data will be evidence of a crime in only certain kinds of cases and will not normally be evidence of a crime when investigators need to learn the current location of someone who committed a past crime. ${ }^{158}$

Magistrate Judge Susan K. Gauvey amplified this analysis in a recent decision when she concluded that a probable cause search warrant does not permit law enforcement to acquire GPS location information solely to execute an arrest warrant. ${ }^{159}$ Specifically, the court noted that the government's "probable cause" theory for obtaining the GPS location data to locate the subject of the arrest warrant was that the "evidence sought will aid in a particular apprehension," not that it was evidence of a crime itself. ${ }^{160}$ The government's request was for "broad information concerning [a] defendant's ongoing location" with no alleged relationship whatsoever between the "defendant's ongoing movements and his crime."161 The court therefore reasoned that, because the government had not established the "requisite nexus between the information sought and the alleged crime, no search warrant may issue" for the location data. ${ }^{162}$

Moreover, in certain circumstances, law enforcement may compel historical location information to exclude someone from a criminal investigation. In that instance, the location information would not, under any reasonable stretch of Rule 41, be evidence of a crime but rather would serve the important function of "clearing" someone of criminal activity. Clearing a suspect would thus prevent further investigation, potentially avoiding a needless expenditure of government resources and a gratuitous government intrusion into his life by focusing the investigation more accurately upon the true perpetrator. These are just a few examples of how the "evidence of a crime" element of Rule 41 may not encompass important law enforcement investigative activities. To the extent that good policy may dictate a probable cause standard for location information, that standard would need to accommodate the diverse, legitimate uses of location information by law enforcement.

157. Id.

158. Id.

159. In re Application of the U.S. for an Order Authorizing Disclosure of Location Info. of a Specified Wireless Tel., No. 10-2188, 2011 U.S. Dist. LEXIS 85638 (D. Md. Aug. 3, 2011).

160. Id. at 93 .

161. Id. at 105 .

162. Id. 


\section{LESSONS LEARNED}

In 2010, the House Judiciary Subcommittee on the Constitution, Civil Rights, and Civil Liberties held three ECPA reform hearings (with Stephanie serving as lead counsel). The second of those hearings, and the most challenging to conceive and execute, explored issues pertaining to law enforcement access of location data (Location Hearing). ${ }^{163}$ The hearing focused on supplying members of Congress with the knowledge necessary to clarify or propose new law enforcement access standards for location information. ${ }^{164}$

Some of the challenges Stephanie encountered in developing this hearing stemmed from factual and policy questions and quandaries that continue to inform the search for reasonable access standards and other reforms that will strike the right balance among the interests of law enforcement, consumer privacy, and industry. This Part discusses these challenges, which now motivate and shape the recommendations for the policy framework presented later in this Article.

\section{A. ACQuiring Facts To Make Good Policy Is Difficult}

Location technology and the uncertain legal landscape governing law enforcement access to location information are complex subjects. As with most complicated issues, Congress needs information from all stakeholders - in this case from law enforcement, consumer privacy and civil liberties advocacy groups, and industry representatives - to judge the relative necessity for legislative action and discern the best directions for policy. When compared, however, with other new technologies prompting Subcommittee consideration of ECPA reform, such as cloud computing, the subject of location-based information and services inspires an unusual degree of secrecy on the part of both industry and law enforcement.

At a later Subcommittee ECPA reform hearing focused on cloud computing, five major cloud computing companies testified. ${ }^{165}$ Industry testimony included explanations of business models and services offered by the various cloud companies and a discussion about how current ECPA standards are often difficult to apply to cloud services like Google Docs and

163. See Location Hearing, supra note 19.

164. See id.

165. See generally ECPA Reform and the Revolution in Cloud Based Computing: Hearing Before the Subcomm. on the Constitution, Civil Rights, and Civil Liberties of the H. Comm. on the Judiciary, 111th Cong. (2010) [hereinafter Cloud Based Computing Hearing], available at http://judiciary.house. gov/hearings/printers/111th/111-149_58409.PDF. Industry witnesses included representatives from Google, Microsoft, Salesforce, Rackspace, and Amazon. 
Google Calendar. ${ }^{166}$ Moreover, some of these companies asserted that weak ECPA privacy protections for information stored "in the cloud," versus the full Fourth Amendment protections afforded information stored on personal laptops, limits the expansion of the cloud market, particularly to foreign customers who are concerned that the U.S. government has overly broad access to cloud-stored information. ${ }^{167}$

In contrast to that very public cloud computing discussion, no wireless carriers or other providers of location-based services to consumers testified at the location hearing. While industry witnesses willingly discussed details about cloud-based services, as well as the challenges the law presents for the industry's compliance with law enforcement requests for information stored in the cloud, no similar public discussion occurred vis-à-vis law enforcement requests for location information or the types of location information carriers collect and retain.

Law enforcement is equally reticent to discuss publicly the investigative practices and processes they employ to obtain location information. While they willingly talk about how critical location information is for a variety of enforcement responsibilities, ${ }^{168}$ they will confirm only very general information about the acquisition and uses of the location data. Of course, when overly detailed information about sources and methods becomes public, these sources and methods may cease to be useful investigative tools. ${ }^{169}$ But, unlike Wiretaps or Pen/Trap surveillance, Congress does not even have a sense of the number and scope of law enforcement requests for

166. See id. at 20 (statement of Richard Salgado, Senior Counsel, Law Enforcement \& Info. Sec., Google Inc.).

167. See id. at 40 (testimony of David Schelhase, Exec. Vice President \& Gen. Counsel, Salesforce.com) (explaining that customers considering storing their information in the cloud want assurances that the U.S. government will not access their data without appropriate due process).

168. See Senate Judiciary 2011 ECPA Hearing, supra note 7, at 5 (testimony of James A. Baker); see also Location Hearing, supra note 19, at 60-61 (written statement of Richard Littlehale, Assistant Special Agent in Charge, Technical Servs. Unit, Tenn. Bureau of Investigation) (describing how cell phone location information frequently permits law enforcement an opportunity to find and rescue a victim or apprehend an offender in a matter of hours).

169. We are not in a position to assess all of the circumstances where location information as an investigative tool could become less useful to law enforcement upon more disclosure about the method and frequency of this tool. We do note, however, that cellphones are increasingly becoming a necessary tool for society, and as a result, it is extremely difficult to avoid the possibility of location surveillance without turning off a phone, and losing all the benefits of that technology. 
location information, statistics that would not necessarily require the exposure of detailed sources and methods. ${ }^{170}$

While we can debate the motivations for the lack of detailed information in the public record about industry and law enforcement practices pertaining to location information, at the end of the day, Congress needs comprehensive information to legislate good policy. For both Wiretap and Pen/Trap authorities, for example, Congress mandated annual Wiretap and Pen/Trap reports, recognizing the need for accurate reporting on law enforcement's use of these tools. ${ }^{171}$ As Senator Patrick Leahy has stated, reporting requirements are a "far more reliable basis than anecdotal evidence on which to assess law enforcement needs and make sensible policy in this area," ${ }^{\prime 72}$ as well as providing some degree of transparency and oversight of these surveillance powers. ${ }^{173}$ No reporting requirements currently exist for location information. ${ }^{174}$ Back in 2000, however, the Republican-controlled House Judiciary Committee proposed legislation concerning law enforcement access standards for prospective location information. ${ }^{175}$ This bill included new reporting requirements that would have given Congress some sense of the scale of law enforcement compelled disclosures, as well as the number of people whose data was provided to law enforcement. ${ }^{176}$ The

170. See generally Christopher Soghoian, The Law Enforcement Surveillance Reporting Gap (Apr. 10, 2011) (unpublished manuscript), available at http:// ssrn.com/abstract $=1806628$.

171. See 18 U.S.C. \2519(2)-(3) (2010) (outlining what the intercepted communications report issued by the Administrative Office of the United States Courts must contain). These reports are detailed, revealing for each wiretap the city or county where it was executed, the type of interception (phone, computer, pager, fax), the number of individuals whose communications were intercepted, the number of intercepted messages, the number of arrests and convictions that resulted from interception, as well as the financial cost of the wiretap. See also id. $\$ 3126$.

172. 145 CONG. REC. 30,868 (1999) (statement of Sen. Leahy).

173. S. REP. NO. 90-1097, at 79 (1968), reprinted in 1968 U.S.C.C.A.N. 2112, 2196 ("[The wiretap reports] are intended to form the basis for a public evaluation of its operation. The reports are not intended to include confidential material. They should be statistical in character. ... [They] will assure the community that the system of court order electronic surveillance envisioned by the proposed chapter is properly administered and will provide a basis for evaluating its operation.”).

174. See Soghoian, supra note 170 , at 22.

175. See Electronic Communications Privacy Act of 2000, Digital Privacy Act of 2000 and Notice of Electronic Monitoring Act: Hearing Before the Subcomm. on the Constitution, Civil Rights, and Civil Liberties of the H. Comm. on the Judiciary, 106th Cong. (2000) [hereinafter House Judiciary 2000 ECPA Hearing].

176. See Digital Privacy Act, H.R. 4987, 106th Cong. (2000). While the DOJ opposed the particular formulation of these reporting requirements because they were overly burdensome, they could be structured to be less onerous on investigators and prosecutors. See House Judiciary 2000 ECPA Hearing, supra note 175, at 51 (statement of Kevin DiGregory, Deputy Assoc. Attorney Gen., Dep't of Justice) (" $[\mathrm{T}]$ he imposition of such extensive 
bill did not become law and now, more than ten years later, Congress has little more information than it did in $2000 .{ }^{177}$

\section{B. The Singular Advocacy Focus on Law ENFOrCEMENT StANDARdS Has NARrowed a Discussion THAT SHOUld INCLUDE MINIMIZATION AND OTHER "DOWNSTREAM" PRIVACY PROTECTIONS}

The advocacy regarding the appropriate standard for law enforcement access to location information has largely focused on the DDP Coalition principle calling for a Rule 41 probable cause requirement for all law enforcement compelled disclosures of location information (historical and prospective, regardless of accuracy). ${ }^{178}$ This unitary standard, however, is a "non-starter" for law enforcement insofar as it will unduly limit the acquisition of non-content information at the early stages of an investigation and will likely prohibit some basic investigative uses of location information. ${ }^{179}$ Indeed, it is one side of what has appeared to become a rather intractable stalemate.

The singular advocacy focus on a "high" law enforcement access standard unduly limited a discussion of other downstream, post collection privacy protections, which were neither included in the DDP proposal nor adequately considered publicly. Such additional protections are a significant component, along with reasonable access standards, in the broader privacy framework proposed in Part VI. Such measures, mandated by Congress for other surveillance authorities, include: minimization, a process by which information not relevant to the investigation is purged from law enforcement databases; ${ }^{180}$ notice to individuals whose location information has been disclosed to law enforcement at a time that does not harm an ongoing investigation; ${ }^{181}$ and the publication of statistical reports on law enforcement use of location surveillance authorities. ${ }^{182}$ These sorts of protections are one

reporting requirements for cyber-crime investigators would come at a time when law enforcement authorities are strapped for resources to fight cyber-crime. The reporting requirements for wiretaps, while extensive, are less onerous because law enforcement applies for such orders relatively rarely. Extending such requirements to orders used to obtain mere transactional data would dramatically hinder efforts to fight cyber-crime, such as the distribution of child pornography and Internet fraud.").

177. See Soghoian, supra note 170 , at 23.

178. See Our Principles, supra note 22.

179. See supra Part III.

180. See 18 U.S.C. \2518(5) (2010); 50 U.S.C. \1804(a)(5) (2009); id. \1861(b)(2)(B).

181. See 18 U.S.C. $\int 2518(8)(d)(1998)$.

182. See 18 U.S.C. $\$ 2519$ (2010). 
way to balance or offset access standards authorizing broader law enforcement collection of data.

\section{The Polarized Views of LaW Enforcement and Privacy Advocates Make Consensus Building Difficult}

It is not particularly insightful to observe that when one side of a debate starts from a position that is completely unworkable for the other side and will not move, it is difficult to build consensus. If, at the end of the day, the only standard for location data that is acceptable to privacy advocates is a Rule 41 probable cause standard, then they risk letting the proverbial perfect be the enemy of the good. The advocacy message for overall ECPA reform-while supported through industry participation in the DDP Coalition and echoed by strong industry voices outside of the coalition calling for Congress to enact clear legal rules and shelter industry from liability — was driven primarily by privacy advocates. Thus, the burden to suggest new, workable, and more privacy-protective standards falls primarily on the shoulders of the community of privacy advocates. This is not an area where law enforcement will likely act as a willing catalyst for new access standards that place restrictions on their own investigative tools in the name of better privacy protections, even if they are prepared to agree to a fair compromise in the end. Moreover, law enforcement has strong advocates in Congress who will fight against overly broad proposals to restrict investigative authorities. Consider, for example, the opening statement by then Ranking Member Sensenbrenner (now Chairman of the House Judiciary Subcommittee on Crime, Terrorism, and Homeland Security and author of the USA PATRIOT Act) at the Location Hearing. Having clearly read the proposal for a unitary probable cause standard, the Ranking Member announced, "While there may very well be a need to clear up the confusion in the area of obtaining prospective cell site information, it does not necessarily follow that the appropriate remedy to any ambiguity would be a Rule 41 search warrant based upon probable cause."

Notwithstanding such strong allies in Congress, however, the DOJ should carefully measure the practical impact of Jones. While Jones does not hold that a warrant is required for the installation and use of a GPS tracking device, ${ }^{184}$ a prudent prosecutor interested in ensuring that GPS tracking

183. Location Hearing, supra note 19, at 3 (opening statement of ranking member Rep. Jim Sensenbrenner).

184. The Court declined to reach the question of whether a warrant is required to install a GPS device. See United States v. Jones, 132 S. Ct. 945, 954 (2012) ("The Government argues in the alternative that even if the attachment and use of the device was a search, it was reasonable-and thus lawful-under the Fourth Amendment because 'officers had 
evidence is admissible at trial would, absent further judicial or congressional guidance, be wise to obtain one in every instance. Only time will tell whether this new strategic necessity will have a measurable adverse impact on law enforcement investigations.

A more urgent concern for the DOJ, however, should be the threat of continued judicial application and expansion of the mosaic theory inspired by the signals in the Jones concurrences. The signals in the Jones concurrences indicate that a majority of the Court could, in the future, incorporate some version of the theory into its Fourth Amendment jurisprudence. As we have seen, absent clear congressional guidance regarding standards for law enforcement access to location data, some courts are already applying the mosaic theory to government applications for historical cell location data with varying interpretations about how much data forms a mosaic and triggers a Fourth Amendment issue. ${ }^{185}$ Justice Alito's answer for how to deal with the thorny line drawing problem under a theory that does not define when the mosaic materializes is simple: "where uncertainty exists with respect to whether a certain period of GPS surveillance is long enough to constitute a Fourth Amendment Search, police may always seek a warrant."186 But this simple dictate is hardly a viable one for law enforcement in every instance. ${ }^{187}$ If the DOJ finds this potential reality to be unworkable and harmful to future law enforcement investigations (as it has suggested in congressional testimony), ${ }^{188}$ it should engage earnestly in the legislative process and be prepared to agree to some reasonable additional privacy protections. Indeed, the prospect of a majority that would make the mosaic

reasonable suspicion, and indeed probable cause, to believe that [Jones] was a leader in a large-scale cocaine distribution conspiracy.' We have no occasion to consider this argument. The Government did not raise it below, and the D.C. Circuit therefore did not address it." (citation omitted)); see also Orin S. Kerr, What Jones Does Not Hold, VolOKH CONSPIRACY (Jan. 23, 2012), available at http://volokh.com/2012/01/23/what-jones-does-not-hold/ ("[W]e actually don't yet know if a warrant is required to install a GPS device; we just know that the installation of the device is a Fourth Amendment 'search.' ").

185. See supra Section III.B.2.b.

186. Jones, 132 S. Ct. at 964 (Alito, J., concurring).

187. See supra Section III.A.3.

188. See Senate Judiciary 2011 ECPA Hearing, supra note 7, at 5 (testimony of James A. Baker, Assoc. Deputy Attorney Gen., U.S. Dep't of Justice) ("If an amendment [to ECPA] were to unduly restrict the ability of law enforcement to quickly and efficiently determine the general location of a terrorist, kidnapper, child predator, computer hacker or other dangerous criminal, it would have a very real and very human cost."). 
theory the law of the land should concentrate the Department's mind wonderfully upon resolving this issue through the legislative process. ${ }^{189}$

\section{WHAT IS THE HARM, AND WHO CAN ADDRESS IT MOST EFFECTIVELY?}

In proposing that Congress reform existing location privacy law, we confront a logical threshold question: just what harms would we seek to prevent? When it first enacted the Electronic Communications Privacy Act back in 1986, Congress sought to reestablish the balance of interests between law enforcement and privacy ${ }^{190}$ that had been upset-to the detriment of privacy-by advances in wireless and computing technologies. ${ }^{191}$ Congress also recognized that consumers might not embrace new technologies if privacy interests were not appropriately protected. ${ }^{192}$ As technology continues to develop-simultaneously enriching our lives and facilitating more prevalent government (and private) surveillance-Congress, once again, is preparing to confront the task of establishing an appropriate balance among stakeholder equities, ${ }^{193}$ which prompts us, yet again, to ask this threshold question.

In recent years, prominent judges have, in written opinions, described and voiced concern over the harms associated with modern location tracking technologies. In doing so, they have suggested that Congress, not the judiciary, might be in the best position to provide appropriate incentives and

189. "Depend upon it, Sir, when a man knows he is to be hanged in a fortnight, it concentrates his mind wonderfully." JAMES BOSWELL, LIFE OF JOHNSON 849 (Oxford Univ. Press 1960) (1791).

190. See House Judiciary 2010 ECPA Reform Hearing, supra note 18, at 8-9 (written statement of James X. Dempsey, Vice President for Pub. Policy, Ctr. for Democracy \& Tech.) (discussing balance of interests Congress sought to strike in enacting ECPA).

191. Among the developments noted by Congress were "large-scale electronic mail operations, cellular and cordless phones, paging devices, miniaturized transmitters for radio surveillance, and a dazzling array of digitized networks . . ." H.R. REP. NO. 99-647, at 18 (1986). Privacy, Congress concluded, was in danger of being gradually diminished as technology advanced. S. REP. NO. 99-541, at 2-3, 5 (1986); see also H.R. REP. No. 99-647, at 18 (stating that "legal protection against the unreasonable use of newer surveillance techniques has not kept pace with technology").

192. See S. REP. NO. 99-541, at 5 (noting that legal uncertainty over the privacy status of new forms of communications "may unnecessarily discourage potential customers from using innovative communications systems"); see also H.R. REP. NO. 99-647, at 19 (noting that legal uncertainty over confidentiality "may unnecessarily discourage potential customers from using ... [new] systems").

193. As of the writing of this Article, five separate hearings on ECPA reform were held during the 111th and 112th sessions of Congress (three hearings held in the House Judiciary Committee and two hearings in the Senate Judiciary Committee). 
remedies. We take our cue from these judges and their stated concerns to identify potential harms Congress should consider when it evaluates the relative necessity for legislative action and discerns the best policy direction. ${ }^{194}$

\section{A. The Government's Gaze And the Panoptic EFfect}

As we shall see, some judges who have considered cases involving law enforcement access to location data posit that the persistent gaze of government may itself represent an objective harm to the public. ${ }^{195}$ In doing so, these judges have alluded to surveillance theories found in literature, social theory, and philosophy. To evaluate and discuss their conclusions fully, we must briefly describe some of that material and how it appears, directly or allusively, in their opinions.

Late eighteenth-century theories of surveillance as an instrument to administer discipline and enforce social control, such as Jeremy Bentham's "Panopticon" prison architecture, ${ }^{196}$ suggest that the potency of the government's gaze is such that, when imposed strategically and with suggested if not actual universality and constancy, it becomes internalized in the very minds of those subjected to its influence as a mechanism of rehabilitative discipline. ${ }^{197}$ Moreover, Bentham envisioned the Panopticon's design as appropriate not only to prisons, but to any environment where enhanced discipline is desired: schools, asylums, factories, and more. In short, for Bentham, the panoptic gaze of the state could serve as a secular version of the all-seeing eye of the Judeo-Christian God, and the normative behavioral conformity religious conscience once inspired would be supplanted on more certain ground by the discipline this modern gaze could inspire.

The twentieth-century French social theorist Michel Foucault rigorously analyzed Bentham's project in the Panopticon and expanded it into an interpretive metaphor for coercive social power. Foucault examines "Panopticism" as an instance of modern society's ability to compel

194. What follows in this Section is not an attempt to describe an authoritative legal or philosophical theory of the harms inherent in unjustified disclosure of location data, though we shall have occasion to allude to law, philosophy, and literature in service of the task of describing those harms as expressed by judges who have confronted them and chosen to discuss them in recent opinions.

195. See United States v. Cuevas-Perez, 640 F.3d 272, 285 (7th Cir. 2011) (Flaum, J., concurring) ("The constitutional ill of prolonged or mass use of GPS technology would not necessarily be based on the information acquired by the device but on the fact of the government's gaze.”).

196. See Jeremy Bentham, The Panopticon Writings 29-95 (Miran Bozovic ed., 1995) (1787).

197. Id. 
compliance with its approved behavioral norms through its institutions and their various discourses. ${ }^{198}$ The presence of modern surveillance mechanisms, visible and imperceptible, public and private, promotes the "Panoptic effect"- a general sense of being omnisciently observed. The state may choose to deploy this effect to amplify and mystify the power of its own "gaze" as a coercive instrument, and to promote the internalization of that gaze in the service of discipline. ${ }^{199}$

Bentham's plan for the Panopticon was fairly simple: a model prison consisting of a central tower surrounded by a ring of prison cells, each of them backlit, so that anyone in the tower could see all of the prisoners at once. Bentham posited that a single inspector in the tower could control the behavior of all of the prisoners through making each prisoner "always feel themselves as if under inspection, at least as standing a great chance of being so." ${ }^{200}$ Eventually, since the backlit cells and the tower structure made it impossible for prisoners to observe him, the monitor in the tower would actually become superfluous and the inmates, having internalized the presumption of his continued surveillance, would literally watch themselves.

198. See Michel Foucault, Discipline \& Punish: The Birth of the Prison 195228 (1978). Discourse in this case does not refer merely to the word's common denotation as written or spoken communication or debate, but to the word as used in modern social theory, particularly the work of Foucault, referring to the various systems of linguistic usages associated with complex social practices (e.g., law, medicine, religion) deployed as instruments of social power, particularly the power of the state. See generally MICHEL Foucault, The Order of Things (1970); Michel Foucault, The Archeology of KNOWLEDGE (1972). For an extended discussion of the diffuse nature of power in society and the role this concept of discourse plays in analyzing how ideas and language encode power in social spaces and, therefore, have the potential to play a role in historical change, see Michel Foucault, Two Lectures, in Power/KnOwledge: SElected InTERviews \& OTHER WRITINGS 78 (Colin Gordon ed., 1980).

199. It is important to note that more recent writers on "surveillance theory" have qualified Bentham and Foucault usefully. See, e.g., Gilles Deleuze, Postscript ON THE SOCIETIES OF CONTROL 3-7 (1992) (distinguishing Foucault's "disciplinary" society from his own "control" society in critique of the Panopticon); DAVID LYON, THEORIZING Surveillance: The Panopticon and Beyond (2006); David Lyon, Surveillance STUDIES: AN OVERVIEW 54-62 (2007) (summarizing contemporary criticism qualifying the application of Foucault's analysis to contemporary surveillance). While the rigor and depth of recent surveillance theory is indispensible background to anyone who would consider surveillance in all its profundity, its presence in legal opinions to date, which is the focus in this Article, has been predominantly restricted to metaphorical allusions to Orwell's dystopia in 1984 and some consideration of the government's "gaze" as discussed in Foucault's interpretation of the Panopticon. Since these interpretive frames are effectively canonical and, as such, disseminated commonly enough to drive judicial decision making, as well as the appeal by the judiciary for legislation in this area, we place our own main focus on them at this moment in the policy debate.

200. Jeremy Bentham, Letter V: Essential Points of the Plan, in BENTHAM, supra note 196. 
Foucault claimed this internalization of surveillance made the Panopticon a quintessential figure for a peculiarly modern and secular form of state power that arose in the Enlightenment, "a new mode of obtaining power of mind over mind, in a quantity hitherto without example."201

As modern location surveillance techniques increase in precision and their pervasive distribution throughout society becomes known, though the instruments themselves may or may not remain invisible, people become increasingly aware of, and potentially influenced by, a palpable sense of the omniscient gaze similar to that produced by Bentham's prison design.

Consider, for example, that through the use of modern surveillance technologies, a single police officer can now monitor the movement of tens, even hundreds, of targets from the comfort of her desk ${ }^{202}$ and, because there is no statutory notice provided to those under such surveillance, targets have no way of knowing if and when they are being or have been watched. ${ }^{203}$ While surveillance has traditionally been very expensive in terms of human resources (often requiring multiple shifts of agents to watch a single target for a twenty-four-hour period), the ubiquity of cellular phones and innovations in GPS tracking technology has made surveillance easier, cheaper, and consequently more prevalent. ${ }^{204}$ A law enforcement agency's gaze is no longer limited by the number of agents available to drive around a city, but only by the amount of money available in its budget to pay wireless carriers for their assistance, or to purchase GPS tracking devices or other similar technologies. ${ }^{205}$ Moreover, although such surveillance is supposed to

201. Id. at Preface.

202. United States v. Pineda-Moreno, 617 F.3d 1120, 1124 (9th Cir. 2010) (Kozinski, J., dissenting from denial of rehearing en banc).

203. See Appeal of In re W.D. Pa. Application, 620 F.3d 304, 317 (3d Cir. 2010) (noting that "it is unlikely that cell phone customers are aware that their cell phone providers collect and store historical location information").

204. See United States v. Garcia, 474 F.3d 994, 998 (7th Cir. 2007) ("The new [surveillance] technologies enable, as the old (because of expense) do not, wholesale surveillance. ... Technological progress poses a threat to privacy by enabling an extent of surveillance that in earlier times would have been prohibitively expensive.").

205. Christopher Soghoian, An End to Privacy Theater: Exposing and Discouraging Corporate Disclosure of User Data to the Government, 12 MiNN. J.L. SCI. \& TECH. 191, 222-23 (2011). ("Many telecommunications companies and ISPs seek and typically receive payment from government agencies for the surveillance services they provide, a practice that the law often permits."). The cost of location surveillance by some carriers appears to have plummeted over the past decade - a savings that they were obligated to pass on to law enforcement, though no public data exists for comparison. For example, in 2003, Nextel communications charged \$150 per “ping." See Nextel, SubPOENA \& CourT Orders: NeXTEL’s Guide FOR LAW ENFORCEMENT 6 (2003), available at http://info.publicintelligence.net/nextelsubpoena. pdf. In 2009, it was revealed that law enforcement agencies had performed 8 million pings 
be invisible, it is becoming more perceptible through media stories, making the fact of its pervasive existence known, at least in an abstract sense. ${ }^{206}$ This simultaneous visible and invisible presence of surveillance is precisely what produces the anxiety that is the foundation of the panoptic effect. ${ }^{207}$ These particular location technologies partake of a whole system of surveillance instruments and mechanisms, both governmental and private, which construct and project the government's gaze. ${ }^{208}$

Echoing the conclusions hinted at by the history of surveillance, its coercive utility, and the rapid innovation in contemporary surveillance technology, including geolocation systems, Seventh Circuit Judge Flaum, while criticizing the reasoning of Maynard in Cuevas-Perez, suggests that the fact of the "government's gaze" itself, as exerted by "mass use of GPS

via a website created by Sprint/Nextel. See Pineda-Moreno, 617 F.3d at 1125 (Kozinski, J., dissenting from denial of rehearing en banc). Although we have no direct evidence to suggest that the carrier has reduced the cost of its pings (or moved to a fixed fee, rather than per-ping charges), even without adjusting for inflation, had Sprint charged $\$ 150$ for each of the 8 million pings, it would have made $\$ 1.2$ billion. Since law enforcement certainly did not spend that much money for this purpose, some new billing arrangement must have motivated the increased activity level.

206. See generally The Wire (HBO cable television series, 2002-2008); see also Anders Albrechtslund, Surveillance and Ethics in Film: Rear Window and The Conversation, $15 \mathrm{~J}$. CRIM. JUst. \& POPUlar CUlTuRE, no. 2, 2008, at 129-44.

207. Regarding the "Panoptic effect" of the state's gaze, Professor Daniel Solove points out that:

Although concealed spying is certainly deceptive ... [i]t is the awareness that one is being watched that affects one's freedom. . . . A more compelling reason why covert surveillance is problematic is that it can still have a chilling effect on behavior. In fact, there can be a more widespread chilling effect when people are generally aware of the possibility of surveillance but are never sure if they are being watched at any particular moment.

Daniel Solove, Understanding Privacy 109 (2008). This is true, unequivocally, regarding the specular value of strategically displaying and withholding evidence of state power. Moreover, revelations of the covert commercial use of location-based tools, such as the recently divulged use of Apple's iPhone and Google's Android phones in WiFi mapping, have the indirect effect of reinforcing the general sense of the state's coercive gaze and its power to influence compliance with social norms, whether or not there is any actual convergence of interest between the state and private actors in a given case. See Angwin \& Valentino-Devries, supra note 41.

208. See Christopher Slobogin, Is the Fourth Amendment Relevant in a Technological Age?, FUTURE CONST. (Brookings Inst., Washington, D.C.), Dec. 8, 2010, available at http://www. brookings.edu/ /media/Files/rc/papers/2010/1208_4th_amendment_slobogin/1208_4th _amendment_slobogin.pdf (describing the negative, real world impacts of surveillance even when the government makes no use of the surveillance product). 
technology," may represent a "constitutional ill" which amounts to a cognizable harm. ${ }^{209}$

Historical location information produced by mobile devices adds another layer of implication to the panoptic effect. Such information is, of course, a record of where we have been. These data are stored by companies providing wireless services to consumers and on mobile devices for periods of time unknown to the user since retention policies vary by company. ${ }^{210}$ Some companies may store more precise data than others, ${ }^{211}$ but through these data the government may get an accurate picture of most everywhere we have been. ${ }^{212}$ Moreover, once information is disclosed, the government entities responsible for the investigation add it to databases and keep it for an indefinite period of time. ${ }^{213}$ In effect, modern location technology can give the government an increasingly perfect memory of our activities, thus making it impossible to escape one's past. Data retention policy, at this point, might be considered a relatively unknown and thus "immature" source of panoptic power. We are only now beginning to learn the details and scope of the heretofore hidden commercial use of location data on smartphones, ${ }^{214}$ and Congress is currently considering data retention legislation that will require providers to store subscriber data for twelve months. ${ }^{215}$ These developments

209. United States v. Cuevas-Perez, 640 F.3d 272, 285 (7th Cir. 2011) (Flaum, J., concurring).

210. Soghoian, supra note 205 , at 210 (" $[\mathrm{M}]$ ost technology providers and communications carriers now have established data retention policies that govern the length of time before which they will delete customer records, communications, logs, and other data. Unfortunately, outside of the search engine market, where pressure from European regulators has led to companies publicly touting their policies, few other firms will publicly reveal their own data retention rules.").

211. See Location Hearing, supra note 19, at 27 (written statement of Prof. Matt Blaze, Univ. of Pa.).

212. See People v. Weaver, 12 N.Y.3d 433, 441-42 (2009) (describing the types of information that tracking devices can record about an individual's life).

213. See generally Fred H. Cate, Government Data Mining: The Need for a Legal Framework, 43 HARV. C.R.-C.L. L. REV. 435 (2008). Moreover, the data of innocent individuals who are not targets of government surveillance can get "swept up" by community of interest requests or other compelled disclosures of data that seek to discover everyone who was at or near a particular location at a particular time.

214. See Jennifer Valentino-DeVries \& Julia Angwin, Latest Treasure Is Location Data, WALL ST. J. (May 10, 2011), http://on.wsj.com/xJGP9u ("Location information is emerging as one of the hottest commodities in the tracking industry .... [T] he Journal's 'What They Know' series found that 47 of the 101 most popular smartphone apps sent location information to other companies.").

215. The Protecting Children from Internet Pornographers Act of 2011 was favorably reported out of the House Judiciary Committee on July 28, 2011 and requires certain types of providers to retain some types of data for at least 12 months. See H.R. 1981, 112th Cong. \4 (2011), available at http://1.usa.gov/xeBBB6. 
will inevitably lead to a broader public discussion of both the commercial and law enforcement uses of historical location data. These discussions will ostensibly be conducted in the name of protecting the public from the government's intrusive eye, which will serve ironically to enhance its power to reinforce the panoptic effect.

More than forty years ago, Vice President Hubert Humphrey observed that "[w]e act differently if we believe we are being observed. If we can never be sure whether or not we are being watched and listened to, all our actions will be altered and our very character will change. ${ }^{216}$ Justice Douglas made the same point a few years later, observing that "[m]onitoring, if prevalent, certainly kills free discourse ...." ${ }^{217}$ Humphrey and Douglas both anticipate Foucault in their conclusions in describing the effect of being observed. To these men, one of politics, the other of law, the observing gaze of the state was, intuitively, a powerfully coercive force that changes people, as surely and utterly as the Medusa's gaze was said to change men to stone.

The ever-improving accuracy of location technology has given the government's gaze a degree of clarity hitherto undreamed of, except perhaps in dystopian novels such as Orwell's 1984. Notably, as they confront the powerful gaze of modern surveillance technologies, judges around the country are voicing their own anxiety regarding the impact of this technology on individuals and society, often turning to sources like Orwell to illustrate their conclusions. In People v. Weaver, a case about a GPS tracking device placed on a car, Judge Lippman expressed his concern over the very personal profile of an individual's life captured by tracking technologies:

The whole of a person's progress through the world, into both public and private spatial spheres, can be charted and recorded over lengthy periods possibly limited only by the need to change the transmitting unit's batteries. Disclosed in the data retrieved from the transmitting unit, nearly instantaneously with the press of a button on the highly portable receiving unit, will be trips the indisputably private nature of which takes little imagination to conjure: trips to the psychiatrist, the plastic surgeon, the abortion clinic, the AIDS treatment center, the strip club, the criminal defense attorney, the by-the-hour motel, the union meeting, the mosque, synagogue or church, the gay bar and on and on. What the technology yields and records with breathtaking quality and quantity is a highly detailed profile, not simply of where we go, but by easy inference, of our associations - political, religious, amicable and amorous, to name only a few-and of the pattern of our

216. Hubert H. Humphrey, Foreword, in EDWARD V. LONG, THE INTRUDERS, at viii (1967).

217. United States v. White, 401 U.S. 745, 762 (1971). 
professional and avocational pursuits. When multiple GPS devices are utilized, even more precisely resolved inferences about our activities are possible. And, with GPS becoming an increasingly routine feature in cars and cell phones, it will be possible to tell from the technology with ever increasing precision who we are and are not with, when we are and are not with them, and what we do and do not carry on our persons - to mention just a few of the highly feasible empirical configurations. ${ }^{218}$

Likewise, in his dissent in United States v. Pineda-Moreno, ${ }^{219}$ a case where the Ninth Circuit rejected en banc review of a panel decision involving GPS technology, the ever-witty ${ }^{220}$ Judge Kozinski turns deadly serious, invoking his own childhood in Communist Romania and alluding directly to the setting of 1984 as he describes the tracking technology in question:

I don't think that most people in the United States would agree with the panel that someone who leaves his car parked in his driveway outside the door of his home invites people to crawl under it and attach a device that will track the vehicle's every movement and transmit that information to total strangers. There is something creepy and un-American about such clandestine and underhanded behavior. To those of us who have lived under a totalitarian regime, there is an eerie feeling of déjà vu. This case, if any, deserves the comprehensive, mature and diverse consideration that an en banc panel can provide. We are taking a giant leap into the unknown, and the consequences for ourselves and our children may be dire and irreversible. Some day, soon, we may wake up and find we're living in Oceania. ${ }^{221}$

218. People v. Weaver, 12 N.Y.3d 433, 441-42 (May 12, 2009).

219. United States v. Pineda-Moreno, 617 F.3d 1120, 1121-26 (9th Cir. 2010) (Kozinski, J., dissenting from denial of rehearing en banc).

220. In criticizing the underlying panel's conclusion that the defendant has no expectation of privacy in his driveway, Judge Kozinski explains:

The panel authorizes police to do not only what invited strangers could, but also uninvited children-in this case crawl under the car to retrieve a ball and tinker with the undercarriage. But there's no limit to what neighborhood kids will do, given half a chance: They'll jump the fence, crawl under the porch, pick fruit from the trees, set fire to the cat and micturate on the azaleas. To say the police may do on your property what urchins might do spells the end of Fourth Amendment protections for most people's curtilage.

Id. at 1123.

221. Id. at 1126. Further, the court in United States v. Sparks refused to find a Fourth Amendment violation in the government's use of GPS placed on the defendant's vehicle under the specific facts of the case, but it nonetheless acknowledged that the court "is not unsympathetic to the sentiment expressed by Chief Justice Kozinski and his Ninth Circuit 
Judge Kozinski's language echoes the disturbing uncertainty that results when the instruments of the state's panoptic gaze become even partially visible. Indeed, as we have discussed, the very partial nature of their visibility is essential to produce the uncertainty and anxiety of the panoptic effect. In response, Judge Kozinski appeals to a locus of greater authority, here an en banc panel of the Ninth Circuit, to assert the control (i.e., "comprehensive, mature and diverse consideration") necessary to govern the state's panoptic gaze in the name of preserving the specifically "American" way of life it seems to threaten.

Judge Flaum, in his concurring opinion in Cuevas-Perez, goes further still, suggesting the government's increasingly powerful and clear sense of sight with regard to the lives of individuals, using new, more accurate location technologies, might offend the Fourth Amendment in a manner explicitly proscribed by the Founders as it was being crafted:

There may be a colorable argument ... that the use of GPS technology to engage in long-term tracking is analogous to general warrants that the Fourth Amendment was designed to curtail, because of the technology's potential to be used arbitrarily or because it may alter the relationship between citizen and government in a way that is inimical to democratic society. ${ }^{222}$

brethren, that there is something 'creepy' about continuous surveillance by the government." 750 F. Supp. 2d 384, 395-96 (D. Mass. 2010). While noting that "[a]dvances in technology, like GPS devices, provide neutral and credible evidence and thus facilitate the ultimate (and yet amorphous) goal of 'justice," " the court also recognizes that "it is easy to envision the worst-case Orwellian society, where all citizens are monitored by the Big Brother government." Id. at 394-95; see also In re Application of the U.S. Authorizing the Release of Historic Cell-Site Info., 809 F. Supp. 2d 113, 127 (E.D.N.Y. 2011) ("While the government's monitoring of our thoughts may be the archetypical Orwellian intrusion, the government's surveillance of our movements over a considerable time period through new technologies, such as the collection of cell-site-location records, without the protection of the Fourth Amendment, puts our county far closer to Oceania than our Constitution permits.").

222. United States v. Cuevas-Perez, 640 F.3d 272, 285 (7th Cir. 2011) (Flaum, J., concurring). In the same case, in her dissent, Judge Wood also appeals to Orwell for interpretive authority, with a sense of urgency matching that of Judges Flaum and Kozinski:

This case presents a critically important question about the government's ability constantly to monitor a person's movements, on and off the public streets, for an open-ended period of time. The technological devices available for such monitoring have rapidly attained a degree of accuracy that would have been unimaginable to an earlier generation. They make the system that George Orwell depicted in his famous novel, 1984, seem clumsy and easily avoidable by comparison.

Id. at 286 (Wood, J., dissenting). 
Judge Flaum's concurrence strongly criticizes the reasoning of the Maynard court $^{223}$ (the case concluding that United States $v$. Knotts ${ }^{224}$ does not govern prolonged GPS surveillance and instead applying a mosaic theory of the Fourth Amendment), yet he seems to go out of his way to propose an alternative theory of the Fourth Amendment that might, perhaps, offer a way to cabin or control the government's prolonged use of GPS tracking. This palpable concern on the part of senior jurists from two appellate courts is indicative of the general harm to society, to which all others are ancillary, created by location technology, and the issues this technology raises should be scrutinized accordingly.

But where should one turn for sufficient authority? A Ninth Circuit en banc panel? How about the ultimate authority in the judicial branch: the Supreme Court of the United States? Judge Flaum considers that option briefly, perhaps aware of the government's petition for certiorari in Maynard, later granted in Jones, ${ }^{225}$ in further reducing his argument to its bare bones: "on this view, the constitutional ill of prolonged or mass use of GPS technology would not necessarily be based on the information acquired by the device but on the fact of the government's gaze.",226

It may be tempting, as a judge on a federal appellate court, to urge the Supreme Court to employ the Fourth Amendment against the "ill" that can be inflicted by the mere "fact of the government's gaze." But Judge Flaum himself, having indulged in the Fourth Amendment argument and perhaps gauging the limited power of the judiciary to use the common law in an effort to assert control of technology changing at the pace of Moore's Law, ${ }^{227}$ immediately withdraws it in favor of a legislative remedy:

223. Id. at 280 (Flaum, J., concurring) ("Neither of Maynard's twin bases for ruling that the defendant had an objectively reasonable expectation of privacy is doctrinally sound-or all that workable as a practical matter.").

224. 460 U.S. 276 (1983) (holding that a person does not have a reasonable expectation of privacy in movements from one place to another on public thoroughfares).

225. See Petition for Writ of Certiorari, United States v. Jones, 132 S. Ct. 945 (2012) (No. 10-1259).

226. Cuevas-Perez, 640 F.3d at 285 (7th Cir. 2011) (Flaum, J., concurring).

227. Moore's law describes a long-term trend in the development of computer hardware, specifically that the number of transistors that can be placed inexpensively on an integrated circuit doubles approximately every two years, resulting in a corresponding, roughly exponential, increase in the capabilities of many digital devices-processors, computer memory, digital camera resolution, and more. Moore's projected rate of growth, which is used in the semiconductor industry to guide long-term planning and to set targets for research and development, has continued for over fifty years and is expected to remain constant through at least 2015 or later. It was named for Gordon E. Moore, the co-founder of Intel, who described the trend in a 1965 paper. Gorden E. Moore, Cramming More Components onto Integrated Circuits, 38 ELECTRONICS, no. 8, Apr. 19, 1965, available at 
Of course, the Supreme Court just last term reminded us that " $[t]$ he judiciary risks error by elaborating too fully on the Fourth Amendment implications of emerging technology before its role in society has become clear." City of Ontario v. Quon, 130 S. Ct. 2619, 2629 (2010). In light of Knott's holding and Quon's admonition, it strikes me not so much as insufficiently circumspect as simply beyond our mandate to conclude that what is permissible when accomplished with a beeper is impermissible when accomplished with a GPS unit. I agree with the dissent, however, that nothing would preclude Congress from taking the important questions implicated by GPS technology and imposing answers. Indeed, the unsettled, evolving expectations in this realm, combined with the fast pace of technological change, may make the legislature the branch of government that is best suited, and best situated, to act. ${ }^{228}$

The Supreme Court has now decided Jones. Where do we find ourselves? The concurring opinions echo the concerns Judge Kozinski and Judge Flaum expressed. Justice Alito's concurrence recognizes that law enforcement's secret, long-term monitoring of every single movement of an individual's car does not accord with society's reasonable expectations of privacy. ${ }^{229}$ Justice Sotomayor even quotes Judge Flaum's concurrence in Cuevas-Perez as she asserts: "GPS monitoring-by making available at a relatively low cost such a substantial quantum of intimate information about any person whom the Government, in its unfettered discretion, chooses to track-may 'alter the relationship between citizen and government in a way that is inimical to democratic society." ",230

The majority opinion, however, functions only to limit the scope of the "government's gaze" with respect to the physical attachment and use of a GPS tracking device. Indeed, the majority's definition of "search" does not apply to situations where the transmission of radio or other electronic signals is not attained through the government's physical attachment of a device by trespass. Moreover, Justice Alito's adoption of a mosaic-type theory raises

http://download.intel.com/museum/Moores_Law/Articles-Press_releases/Gordon_Moore_ 1965_Article.pdf. See generally Bob Schaller, The Benchmark of Progress in Semiconductor Electronics (Sept. 26, 1996) (unpublished paper), available at http://research.microsoft.com/ en-us/um/people/gray/Moore_Law.html.

228. Cuevas-Perez, 640 F.3d at 285-86 (Flaum, J., concurring) (citing Orin S. Kerr, The Fourth Amendment and New Technologies: Constitutional Myths and the Case for Caution, $102 \mathrm{MICH}$. L. REV. 801, 805-06 (2004) (arguing that Congress should be the primary driver of privacy protections when technology "is in flux")).

229. Jones, 132 S. Ct. at 964 (Alito, J., concurring).

230. Id. at 956 (Sotomayor, J., concurring) (quoting Cuevas-Perez, 640 F.3d at 285) (Flaum, J., concurring)). 
the same thorny line drawing issues presented by Maynard. ${ }^{231}$ Perhaps recognizing the limitations of this approach, Justice Alito acknowledges that " $[\mathrm{t}]$ he best we can do in this case is to apply existing Fourth Amendment doctrine and to ask whether the use of GPS tracking in a particular case involved a degree of intrusion that a reasonable person would not have anticipated." 232 But like Judge Flaum, Justice Alito recognizes that "[i]n circumstances involving dramatic technological change, the best solution to privacy concerns may be legislative."233

Certain judges and justices who have closely considered the implications of location technology have expressed concern, even anxiety, over the effects on society of the government's use of location technologies. Some of these jurists have further questioned the law's current ability to contain its effects and have found that ability, and hence their own powers, wanting. We share the jurists' skepticism. Cognizant of the power of the government's gaze and in agreement with Justice Alito's ${ }^{234}$ and Judge Flaum's conclusion that the legislature is likely the branch of government best suited to fashion the appropriate protections against this gaze, we now present our model privacy framework for location information.

\section{LEGISLATIVE PROPOSAL}

In an effort to try and bridge the gap between the currently polarized positions of privacy advocates and law enforcement, we offer a model privacy framework to govern law enforcement compelled disclosures of historical and prospective location information. ${ }^{235}$ It is neither the most

231. See supra Section III.B.2.b.

232. Jones, 132 S. Ct. at 964 (Alito, J., concurring). Furthermore, during the government's oral argument in Jones, shortly following Justice Breyer's stated concern over "what ... a democratic society [would] look like if a large number of people did think that the government was tracking their every movement over long periods of time" and his search for a "reason and principle" that would "reject" this kind of government surveillance "but wouldn't also reject [government tracking] 24 hours a day for 28 days," Justice Scalia exclaimed, "Don't we have any legislatures out there that could stop this stuff?" Transcript of Oral Argument at 24-26, Jones, 132 S. Ct. 945 (2012) (No. 10-1259), available at http:/ / www.supremecourt.gov/oral_arguments/argument_transcripts/10-1259.pdf.

233. Id. (citing Kerr, supra note 228 , at 805-06).

234. Justice Ginsburg, Justice Breyer, and Justice Kagan all signed Justice Alito's concurrence regarding this conclusion.

235. We intend the privacy framework and access standards proposed in this Part only to apply to criminal law enforcement authorities. They are not intended to amend or affect intelligence or national security authorities that the government may use to acquire location information. The government's use of such intelligence tools is beyond the scope of this Article. Any actual legislation that seeks only to amend criminal law enforcement authorities would include appropriate statutory language to exempt relevant intelligence authorities. 
friendly to law enforcement nor the most protective of privacy, but it is an attempt to find a reasonable balance among the interests of law enforcement, privacy, and industry.

Our proposal relies on several overarching principles that form a foundation for crafting the correct balance: a strong privacy framework that does not unduly limit law enforcement investigative activities or negatively affect industry innovation. These principles are influenced by a variety of sources including, but not limited to, ideas expressed by the DDP Coalition, off-the-record discussions with industry representatives, information revealed in public congressional hearings and elsewhere in the public record, and extensive discussions with private practitioners, academics, and privacy advocates.

\section{A. Overarching Principles}

\section{Clear Rules}

Law enforcement, judges, and industry all benefit from clear access standards. ${ }^{236}$ When the ECPA was passed in 1986, location data was not a "routine tool" used by law enforcement and cell phones were a luxury affordable to only a small number of people. Congress, understandably, did not have the clairvoyance to foresee the explosion in wireless mobile devices. Nor did Congress anticipate the confusion ${ }^{237}$ that would ensue due to the lack of any clear guidance in the ECPA in the form of standards governing law enforcement compelled disclosures for prospective location information.

In contrast to the uncertain, even chaotic, legal landscape that currently burdens the analysis of law enforcement access to location data, clear standards enable all stakeholders to execute their respective responsibilities certain in the knowledge that they are following the law. For prosecutors and agents, this means they can efficiently get access to location information because they won't have to "haggle" over the appropriate standard for access with certain judges. For magistrate judges, clear standards better enable them to ensure that the government follows the law in obtaining access to any location data. Moreover, industry can comply with the law without running

236. See Comments of CTIA-The Wireless Association, supra note 46, at 16 ("The lack of a consistent legal standard for tracking a user's location has made it difficult for carriers to comply with location demands."); Senate Judiciary 2011 ECPA Hearing, supra note 7, at 7 (testimony of James A. Baker, Assoc. Deputy Attorney Gen., U.S. Dep't of Justice); Location Hearing, supra note 19, at 85 (written statement of Judge Stephen Wm. Smith, U.S. Magistrate Judge).

237. See supra Part III. 
the current risk of incurring liability for inappropriately disclosing customer information to the government. ${ }^{238}$

\section{Technology Neutrality}

In order for the ECPA to remain a "forward looking statute,"239 even with respect to the next generation of smartphones, it is critical that law enforcement access standards do not depend on the precision and capabilities of particular location technologies, or with the general state of the industry at the time of drafting. There has been an explosion in the growth of location-based services over the past several years. During that time, the precision of the location information these technologies produce has increased dramatically, such that single cell tower data-particularly where enhanced by some of the 350,000 femtocells deployed around the country $^{240}$ - is becoming as accurate as GPS. ${ }^{241}$ Indeed, the rapid pace of innovation, driven by market incentives to enhance the accuracy of locationbased advertising, suggests that location information will continue to become increasingly precise.

A standard that is dependent on the precision of the location data requested creates an unstable, unworkable situation where, for example, certain magistrate judges feel compelled to examine deployment maps of cell towers or seek expert guidance to determine the precision of the location data produced in a particular district. ${ }^{242}$ To foster clear rules that can be applied without undue confusion, ultimately leading to greater stability in the law, Congress should enact law enforcement access standards that are not dependent on the specific precision of location data.

\section{Standards Alone Will Not Achieve the Appropriate Balance}

Most of the privacy community's location information advocacy to date has focused on a "high" standard for law enforcement access. This focus has led to a stalemate with much of the law enforcement community and has put powerful members of Congress "on guard" to protect law enforcement equities. Regardless of the standard required for law enforcement access to

238. See generally Albert Gidari, Jr., Companies Caught in the Middle, 41 U.S.F. L. REV. 535 (2007).

239. See House Judiciary 2010 ECPA Reform Hearing, supra note 18, at 10 (written statement of James X. Dempsey, Vice President of Pub. Policy, Ctr. for Democracy \& Tech.).

240. See Press Release, Informa Telecoms \& Media, supra note 27.

241. See In re 2010 S.D. Tex. Application, 747 F. Supp. 2d 827, 834 (S.D. Tex. 2010) (“As cellular network technology evolves, the traditional distinction between 'high accuracy' GPS tracking and 'low accuracy' cell site tracking is increasingly obsolete, and will soon be effectively meaningless."'); see also supra Section II.F.

242. See supra Sections III.A.2, III.A.3. 
location data, there are some privacy concerns that can only be addressed through post collection process and rules, such as data minimization, subscriber notification, and statistical reporting. A regime of reasonable access standards combined with downstream privacy protections seems to present the best way forward.

\section{Insistence on a Single Location Standard Is a "A Foolish Consistency"243}

As stated in the Introduction, this proposal is not the most privacy protective, the least burdensome to industry, or the most law enforcement friendly. Rather, it is an attempt to eliminate the uncertainty and instability currently plaguing the law and to achieve a balance of equities that is more palatable insofar as it improves the positions of each of these stakeholders in some appreciable way. The process of passing legislation is largely about compromise. As a result, the "right" and politically feasible policy balance may not always create a perfectly "consistent" set of law enforcement access standards or privacy protections, if consistency is to be read as mere verbal or structural symmetry for its own sake.

Some privacy scholars have argued that the law, as a matter of policy, should treat historical and prospective location data the same, specifically calling for a justification for treating them anything other than the same. ${ }^{244}$ Such an approach, however, would be a significant departure from existing statutory surveillance law, which has traditionally treated historical (stored) and prospective (real time) information differently, requiring more process when the government compels real time information. ${ }^{245}$ Insistence upon a

243. "A foolish consistency is the hobgoblin of little minds, adored by little statesmen and philosophers and divines." Ralph Waldo Emerson, Self Reliance, in 2 THE COLLECTED Works of RALPH W. EMERSON: EsSAYs: FIrST SERIES 33 (Joseph Slater et al. eds., 1979) (1841).

244. At the 2011 Privacy Law Scholars Conference, co-sponsored by the law schools at the University of California, Berkeley and The George Washington University, the authors workshopped a draft of this Article. Several privacy scholars and members of the privacy community questioned our justification for treating stored location information differently from real time location data, advocating for a standard that would require a warrant for all location data.

245. For example, the government can use a subpoena to obtain stored telephone toll records, see 18 U.S.C. \$2703(c)(2) (2010), but must get a Pen/Trap order from a court to obtain the same information in real time, see id. \3121. In order to obtain the content of e-mails in real time, the government must meet higher hurdles of a wiretap "super" warrant, which requires a court to find that "normal investigative procedures have been tried and have failed or reasonably appear to be unlikely to succeed if tried or to be too dangerous," $i d$. \2518(c), in addition to several other "probable cause" requirements, see id. \2518 (a)-(b), (d). On the other hand, the government can get stored e-mail content by meeting the standard Rule 41 "probable cause" showing, or less. See \2703(a)-(b); see also Location Hearing, supra 
standard that is "consistent" in the sense only of being identically applied to this distinction would serve only to polarize the legislative process to the point of collapse. Law enforcement will predictably retreat to one corner in order to demonstrate how a probable cause standard for all location data would unduly limit investigative activities ${ }^{246}$ while privacy advocates will just as predictably withdraw support for any legislation that authorizes law enforcement to compel all location information with a unitary standard lower than probable cause. Empathy is lost. Synthesis is precluded. This familiar impasse, which has become the norm in our recent political life, is here the fruit of a foolish consistency that would level a long-held distinction between two categories of data and, in doing so, likely derail a legislative balancing process that could improve the position of all stakeholders when measured against the current state of the law.

As a matter of legislative strategy then, mandating a single standard for the sake of this leveling form of consistency has risks. Such consistency can, of course, cut both ways: it would be equally consistent to allow law enforcement access to all location data with either a probable cause warrant or a D Order. Indeed, consistency for its own sake, argued in either direction, is a reductive, polarizing position that short-circuits any legislative effort to harmonize the competing policy interests of the privacy and law enforcement communities.

\section{B. HOW TO DEFINE LOCATION INFORMATION FOR PURPOSES OF AMENDING THE ECPA}

There are many data forms that reveal an individual's location and that law enforcement can compel from third-party providers. These sources include wireless phone carriers and smartphone platform vendors (such as Apple and Google). Location information can also be discerned through transactional records, such as tollbooth, public transport, and credit card records. ${ }^{247}$ Law enforcement agencies can also obtain location information directly, without going to third parties, by intercepting wireless phone signals

note 19, at 82 (written statement of Judge Stephen Wm. Smith) (explaining levels of privacy protection given to different surveillance authorities).

246. See supra Section IV.B.

247. See Ryan Singel, Feds Warrantlessly Tracking Americans' Credit Cards in Real Time, WIRED (Dec. 2, 2010), http://www.wired.com/threatlevel/2010/12/realtime/ ("Federal law enforcement agencies have been tracking Americans in real-time using credit cards, loyalty cards and travel reservations without getting a court order, a new document released under a government sunshine request shows. ... [S]o-called 'Hotwatch' orders allow for real-time tracking of individuals in a criminal investigation via credit card companies, rental car agencies, calling cards, and even grocery store loyalty programs.”). 
using a Triggerfish, Stingray, or other similar tracking technologies, ${ }^{248}$ or by covertly installing a GPS tracking device under a car. While law enforcement's access to these sources of data all raise legitimate privacy concerns, this Article focuses on the compelled disclosure of location information from communications carriers, such as mobile phone services. Congress can, and should, look into other forms of location surveillance, but they remain beyond the scope of this Article. Our proposed standard, directed at third-party communication carriers, begins with the following statutory definitions:

An "electronic location service" ("ELS") is any service which possesses location information about a customer, subscriber, or user.

"Location information" ("LI") is any information derived or otherwise calculated from the transmission or reception of a radio signal that reveals the approximate or actual geographic location of a customer, subscriber, or user. $^{249}$

"Historical location information" is location information that existed prior to the issuance of an order.

"Current or prospective location information" is location information that comes into existence after a court order for disclosure of that information is issued.

248. Cell Site Simulators, Triggerfish, Cell Phones (last updated Feb. 23, 2007), in U.S. Dep't of Justice, Response to Freedom of Information Act Request No. 07-4130 re: Mobile Phone Tracking 18 (Aug. 12, 2008), available at http://www.aclu.org/pdfs/freespeech/cellfoia_ release_074130_20080812.pdf (stating that Triggerfish can be deployed "without the user knowing about it, and without involving the cell phone provider"); Julian Sanchez, FOLA Docs Show Feds Can Lojack. Mobiles Without Telco Help, Ars TeCHNICA (Nov. 16, 2008), http://arstechnica.com/tech-policy/news/2008/11/foia-docs-show-feds-can-lojack-mobileswithout-telco-help.ars ("The Justice Department's electronic surveillance manual explicitly suggests that triggerfish may be used to avoid restrictions in statutes like CALEA that bar the use of pen register or trap-and-trace devices-which allow tracking of incoming and outgoing calls from a phone subject to much less stringent evidentiary standards - to gather location data.'); see also Jennifer Valentino-DeVries, 'Stingray' Phone Tracker Fuels Constitutional Clash, WALl ST. J. (Sept. 22, 2011), http://on.wsj.com/IhMb7d.

249. "Radio" refers to the radio frequency ("RF") portion of the electromagnetic spectrum, which is "generally defined as that part of the spectrum where electromagnetic waves have frequencies in the range of about 3 kilohertz [ 3000 hertz] to 300 gigahertz." FED. COMmC'Ns COMm'n, Bulletin No. 56, Questions and Answers AbOut Biological EFFECTS AND Potential HaZARDS OF RADIOFREQUENCY ELECTROMAGNETIC FieldS 2-3 (4th ed., 1999), available at http://www.fcc.gov/Bureaus/Engineering_Technology/Documents/ bulletins/oet56/oet56e4.pdf; see also Radio, MERRIAM-WEBSTER DiCTIONARY ONLINE, http:// www.merriamwebster.com/dictionary/radio (last visited Mar. 19, 2012) (defining radio as "of or relating to electric currents or phenomena (as electromagnetic radiation) of frequencies between about 3000 hertz and 300 gigahertz"). 


\section{A STANDARD FOR LAW ENFORCEMENT COMPELLED DisClOSURES OF HisTORICAL LOCATION DATA}

Our proposed law enforcement access standard for historical location information is built around the current D Order standard with the addition of an element specifically requiring courts to examine whether the scope of the request is reasonable in light of the criminal activity being investigated. We have previously discussed certain examples of scope permutations in investigations ${ }^{250}$ - it would be useless to try and define all of them in advance. A discussion of how Congress generally views the scope inquiry could also be developed in legislative history. A court, when applying the standard, will focus the scope of its inquiry on issues raised (and perhaps resolved) by the specific facts presented by the government in its application for a D Order. This standard could be drafted as follows:

(a) DISCLOSURE UPON COURT ORDER.-Except as provided in paragraph (3), a provider of an electronic location service shall provide historical location information to a governmental entity only if the governmental entity obtains a court order issued by any court of competent jurisdiction establishing-

(1) specific and articulable facts showing that there are reasonable grounds to believe that the location information requested is relevant and material to an ongoing criminal investigation; and

(2) specific and articulable facts showing that a reasonable and sufficient nexus exists between the alleged or suspected criminal activity described in paragraph (1) and the scope of the location data requested.

(3) PERMITTED DISCLOSURES WITHOUT COURT ORDER.-A provider of an electronic location service may disclose historical location information with-

(A) the express consent of the customer, subscriber, or the user of the equipment concerned; or

(B) as otherwise authorized in 18 U.S.C. \2702(c)(3)-(6).

By maintaining the "relevant and material" language, our standard preserves law enforcement equities while limiting the unnecessary over-collection of historical location information by requiring courts specifically to approve the scope of a request. Moreover, this standard "forces" the government to articulate how the scope of the request is reasonable in light of the particular

250. See supra Section III.C.1. 
facts and needs of the investigation. ${ }^{251}$ We hope that this type of balancing can foster a compromise between privacy advocates and law enforcement insofar as it does not raise the historical data access standard up to probable cause that would unduly limit law enforcement in the early stages of an investigation, but it does require written justification and court approval for the scope of the request.

This standard also maintains the exceptions for disclosure of non-content records already present in the ECPA, including emergencies involving danger of death or serious physical injury. ${ }^{252}$ Finally, this proposed language clearly establishes the standard the government must meet before obtaining access to historical location data, a change that benefits all stakeholders.

\section{A STANDARD FOR LAW ENFORCEMENT COMPELLED DisClOSURES of Prospective LocAtion DATA}

Our proposed standard for prospective location information requires a probable cause showing. We expand the categories of that showing, however, to accommodate common, legitimate law enforcement uses of prospective location data, including location information pertaining to a person who has committed, is committing, or is about to commit a felony offense or is a victim of that offense.

The DOJ has acknowledged that, as a matter of policy, it already advises prosecutors and agents to obtain a probable cause warrant for GPS or similarly precise location information. ${ }^{253}$ Our standard not only codifies the DOJ's existing practice regarding GPS and similarly precise location data but also requires a probable cause showing (based on the expanded categories) for all prospective location data. Insofar as single cell site data can now be as precise as GPS location information-and such precision will only continue to increase over time-drawing distinctions in the law based upon data precision is no longer logical or workable. ${ }^{254}$

251. Indeed, in Stephanie's experience as a federal prosecutor, when a standard calls for this type of explanation, prosecutors and agents are much more likely to tailor applications narrowly at the outset, in anticipation of court scrutiny.

252. One of the current ECPA exceptions, 18 U.S.C. \2702(c)(6) (2010), puts no limits on providers sharing non-content information with third parties who are not law enforcement. In recent testimony, the DOJ has suggested that it may be appropriate for Congress to consider restricting disclosures of personal information by service providers. See Senate Judiciary 2011 ECPA Hearing, supra note 7, at 10 (testimony of James A. Baker, Assoc. Deputy Attorney Gen., U.S. Dep't of Justice). Insofar as this Article focuses on law enforcement access issues, it is beyond the scope of this Article to address this issue.

253. See Senate Judiciary 2011 ECPA Hearing, supra note 7, at 7 (testimony of James A. Baker).

254. See supra Sections III.A.1, III.B.1, III.C.1, IV.B; see also Location Hearing, supra note 19 , at 85 (written statement of Judge Stephen Wm. Smith). 
With the expansion of the categories of probable cause, we have once again attempted to accommodate law enforcement investigative needs ${ }^{255}$ in order to foster a compromise between law enforcement and privacy advocates. This standard could be drafted as follows:

(1) DISCLOSURE UPON COURT ORDER FOR A PERIOD NOT TO EXCEED 30 DAYS.-Except as provided in paragraph (2), a provider of an electronic location service shall provide a governmental entity current or prospective location information about a customer, subscriber, or user only if the governmental entity obtains a court order from any court of competent jurisdiction issued upon a finding that there is probable cause to believe that-

(A) the information sought is evidence of a crime; or

(B) a person is committing, has committed, or is about to commit a felony offense or is a victim of that offense; and the location information sought to be obtained concerns the location of the person believed to have committed, be committing, or be about to commit that offense or a victim of that offense.

(2) PERMITTED DISCLOSURES WITHOUT COURT ORDER.-A provider of an electronic location service may provide the information described in paragraph (1) -

(A) to a public safety answering point, emergency medical service provider or emergency dispatch provider, public safety, fire service or law enforcement official, or hospital emergency or trauma care facility, in order to respond to the user's call for emergency services;

(B) with the express consent of the customer, subscriber, or the user of the equipment concerned; or

(C) as otherwise authorized in 18 U.S.C. $\$ 2702(c)(3)-(6)$.

(3) DEFINITION.-The term "public safety answering point" means a facility that has been designated to receive emergency calls and route them to emergency service personnel.

(4) EXTENSIONS.-Extensions of such an order may be granted for up to 30 days upon a probable cause showing as defined in sections (A)-(B) of paragraph (1) of this provision.

This statutory language is not from the ECPA reform hearings of 20102011. ${ }^{256}$ Rather, it is adopted from a bill, entitled the "Electronic Communications Privacy Act of 2000," reported out favorably by a

255. See supra Section III.C.

256. See discussion supra Parts I, IV. 
Republican-controlled House Judiciary Committee. The bill never became law, but it applied the "expanded" probable cause standard to prospective location information. ${ }^{257}$ These expanded probable cause standards address situations where, for example, law enforcement may have probable cause to believe someone has committed a crime yet the suspect's current or prospective location information may not itself be evidence of a crime. ${ }^{258}$

Consistent with other real-time surveillance authorities like Pen/Trap and the Wiretap Act, our proposal affords prospective location information a higher degree of privacy protection than that given to previously stored information. ${ }^{259}$ Also mirroring the Wiretap Act, ${ }^{260}$ our proposal places a time limit of thirty days for each individual order, without preventing the government from returning to a court for an extension. This standard also includes specific exceptions to allow for the operation of the E-911 system $^{261}$ while incorporating all of the exceptions for non-content information already present in the ECPA. Finally, this proposed language clearly establishes a standard the government must meet before getting access to prospective location data, a change that again benefits all stakeholders.

\section{E. Post Access Rules and “Downstream” Privacy Protections}

It is obviously important for Congress to select the right legal standard required for law enforcement to obtain location data. Equally important to an overall privacy framework, however, are rules regarding the retention of the data once it is acquired, notice to individuals whose information has been acquired by law enforcement, and reporting requirements to Congress. ${ }^{262}$ Indeed, such "downstream" protections can offset any over-collection of information by law enforcement during the course of an investigation. This Section proposes three specific methods to protect privacy following the

257. See H.R. 5018, 106th Cong. \6(a) (2000).

258. See supra Section III.C.2.

259. See discussion supra note 245 and accompanying text.

260. 18 U.S.C. $\$ 2518(5)(2010)$.

261. Location Hearing, supra note 19, at 36 (statement of Michael Amarosa, Sr. Vice President for Public Affairs, TruePosition Inc.) (describing the FCC E-911 requirement).

262. See Orin S. Kerr, Use Restrictions and the Future of Surveillance Law, FUTURE CONST. (Brookings Inst., Washington, D.C.), Apr. 19, 2011, available at http://www.brookings.edu/ papers/2011/0419_surveillance_laws_kerr.aspx ("[T]he law should still regulate the collection of evidence. But surveillance law shouldn't end there. The shift to computerization requires renewed attention on regulating the use and disclosure of information, not just its collection.”). 
disclosure of location information to law enforcement: minimization, notification, and congressional oversight through statistical reporting. ${ }^{263}$

\section{Minimization}

Given the large amount of data that law enforcement agencies now obtain via location requests and the number of innocent people whose information may be obtained through community of interest requests or requests associated with a specific place, we believe that minimization rules can and should play a role in limiting the privacy harms associated with such data collection. These minimization rules would focus on removing irrelevant location data from law enforcement databases at a time appropriate to the particular investigation or case. Minimization requirements are not a new idea. They already play a privacy protective role in several other surveillance statutes, including the Wiretap Act, ${ }^{264}$ the USA PATRIOT Improvement and Reauthorization Act of 2005 ("PATRIOT Act"), ${ }^{265}$ and the Foreign Intelligence Surveillance Act ("FISA"). ${ }^{26}$

Although Congress has frequently enacted minimization requirements, it has never legislated the specific details of how such minimization would work with respect to particular surveillance authorities or investigations. In both the Wiretap Act and FISA, government lawyers submit minimization protocols as part of their applications, which are then approved by a judge and included in the court order. Likewise, in the PATRIOT Act, Congress directed the DOJ to adopt specific minimization procedures for records

263. There are other types of downstream privacy protections that could and perhaps should eventually be included in a privacy framework-e.g., the unsealing of court orders with appropriate redactions at a time when such unsealing would no longer jeopardize an investigation or place individuals involved in it at risk. See, e.g., Stephen Wm. Smith, Kudzu in the Courthouse: Judgments Made in the Shade, 3 FED. CTS. L. REV. 177 (2009) (arguing that the overabundant, indefinite sealing of certain types of judicial orders undermines the legitimacy of those decisions). For the purpose of making good policy, unsealing, whether after a specified period or after specific conditions have been met, could facilitate greater transparency and provide Congress with better information about how the government uses and courts apply surveillance authorities. Notwithstanding the potential utility of such a policy, however, we believe that the unsealing of court records raises serious security and privacy issues that require a complex and lengthy analysis that is beyond both the scope of ECPA reform and this Article.

264. Title III of the Omnibus Crime Control and Safe Streets Act of 1968 for the first time authorized law enforcement personnel to monitor private telephone conversations. Pub. L. No. 90-351, tit. III, 92 Stat. 197, 211-25 (codified as amended at 18 U.S.C. SS 25112520 (2010)). The Act also provided strict guidelines and limitations on the use of wiretaps as a barrier to government infringement of individual privacy. One of the protections included by Congress was the minimization requirement of 18 U.S.C. $\int 2518(5)$.

265. 50 U.S.C. $\int 1861(\mathrm{~g})(2009)$.

266. Id. \1804(a)(5). 
obtained pursuant to Section 215 orders. Section 215 is a national security collection authority that allows the government to obtain both content and non-content information. ${ }^{267}$

As such, we propose that Congress should require the DOJ, in consultation with State Attorneys General, to develop rules and procedures for the minimization of location information. Such rules would be intended to prevent the retention of information that is not relevant to reasonable law enforcement purposes. Statutory language could be drafted as follows:

The Attorney General, in consultation with State Attorneys General, shall adopt specific minimization procedures governing the retention and dissemination by governmental entities of location information received in response to an order under this section.

In this section, the term "minimization procedures" means specific procedures, reasonably designed in light of the form and purpose of an order for the production of location information, to minimize the retention and prohibit the dissemination of non-publicly available location information concerning non-consenting persons, consistent with the need of law enforcement to obtain, retain, produce, and disseminate information that: 1) is evidence of a crime; or 2) concerns the location of a person who is committing, has committed, is about to commit, or is a victim of a felony offense; or 3) is otherwise relevant and material to an ongoing criminal investigation and to be retained or disseminated for law enforcement purposes.

This language gives the Attorney General, in conjunction with the State Attorneys General, the flexibility and discretion to design minimization rules and procedures consistent with law enforcement needs while minimizing the retention and dissemination of location data that is not or is no longer relevant to legitimate law enforcement purposes.

\section{Notification}

Covert surveillance methods are investigative tools that by their very nature invade the privacy of those targeted and are, as history has shown, prone to abuse. ${ }^{268}$ To ensure these surveillance powers are restricted to

267. Section 1861 of Title 50, commonly referred to as "Section 215 Business Records," permits the government to obtain, with a FISA court order, any "tangible thing" for certain types of national security investigations. Such Section 215 minimization procedures were intended to minimize the retention and prohibit the dissemination of non-publicly available information concerning United States persons consistent with national security interests. See $\int 1861(\mathrm{~g})$.

268. See Julian Sanchez, Wiretapping's True Danger, L.A. Times (Mar. 16, 2008), http:// articles.latimes.com/2008/mar/16/opinion/op-sanchez16 ("Without meaningful oversight, presidents and intelligence agencies can_and repeatedly have-abused their surveillance 
legitimate law enforcement investigative needs, surveillance of innocent persons should be limited whenever possible and, whenever employed, it should not remain secret indefinitely. Such transparency facilitates social and congressional oversight of government use of surveillance techniques: individuals who may have been inappropriately or illegally monitored are provided with information and resulting incentives that may motivate them to pursue personal remedies, such as placing facts about the surveillance in the public record. Indeed, a disclosure mechanism that will raise public awareness of, and stimulate public discourse about, the scope and frequency of government surveillance activities may serve as an important deterrent to gratuitous use or abuse of these powers.

In both the Wiretap Act and the Stored Communications Act, Congress created mandatory notice requirements that guarantee that subjects of some forms of law enforcement surveillance would be told that their communications have been intercepted or accessed. ${ }^{269}$ Such notice provisions act as an important privacy protection that particularly benefits those who are subjects of surveillance but never charged with a crime. While those who are eventually arrested and charged might otherwise learn that they have been the target of surveillance (through the disclosure of search warrants, affidavits, and other documents), those who are not charged would never know about their surveillance histories were it not for the existence of notice requirements in existing surveillance laws.

We propose a similar notice requirement for those individuals whose location information is obtained by law enforcement agencies. This requirement will apply to those individuals targeted in location orders, as well

authority to spy on political enemies and dissenters. ... [A] thorough congressional investigation headed by Sen. Frank Church (D-Idaho) revealed that for decades, intelligence analysts - and the presidents they served-had spied on the letters and phone conversations of union chiefs, civil rights leaders, journalists, antiwar activists, lobbyists, members of Congress, Supreme Court justices-even Eleanor Roosevelt and the Rev. Martin Luther King Jr. The Church Committee reports painstakingly documented how the information obtained was often 'collected and disseminated in order to serve the purely political interests of an intelligence agency or the administration, and to influence social policy and political action.' ").

269. See 18 U.S.C. $\$ 2518(8)(d)$ (Wiretap Act notifications) and $\iint 2703(b)(1)(B), 2705$ (ECPA notifications). ECPA notifications only apply to the disclosure of content (not noncontent) and then only when a $\int 2703$ (d) order or subpoena is used to compel content. If using a Rule 41 warrant to compel content, at least one court held that the government only has to notify the service provider, not the customer or subscriber. In re Application for Warrant for E-mail Account [redacted]@gmail.com Maintained on Computer Servers Operated by Google, Inc., Headquartered at 1600 Amphitheater Parkway, Mountain View, CA, Mag. No. 10-291-M-01 (D.D.C. Nov. 1, 2010) (Lamberth, J.), available at http://www.dcd. uscourts.gov/dcd/sites/dcd/files/mag10-291.pdf. 
as innocent individuals whose information may be obtained as part of disclosures associated with specific places or community of interest requests. In addition to facilitating transparency and providing notice to impacted individuals, this requirement will, similar to existing compensation requirements, ${ }^{270}$ discourage law enforcement agencies from making unnecessary requests for large amounts of data, ${ }^{271}$ as the cost of notifying 200 people will presumably be greater than that of notifying only twenty. This requirement could be drafted as follows:

(a) NOTIFICATION.-

(1) Within 90 days after the disclosure of historical location information, or the expiration of an order authorizing prospective location information, the governmental entity shall serve upon, or deliver by appropriate means, ${ }^{272}$ the customer, subscriber, or user whose location was disclosed with notice that-

(A) states with reasonable specificity the nature of the law enforcement inquiry; and

(B) informs such customer, subscriber, or user that their location information was supplied to that governmental authority, and the date on which such disclosure was made.

(2) Extensions of the delay of notification of up to 90 days each shall be granted by the court upon application by a governmental entity if the court determines that there is reason to believe that notification of the existence of the court order may have an adverse result described in paragraph (3) of this subsection.

(3) An adverse result for the purposes of paragraph (2) of this subsection is-

270. See House Judiciary 2010 ECPA Reform Hearing, supra note 18, at 32 (written statement of Albert Gidari, Perkins Coie LLP) ("When records are 'free,' such as with phone records, law enforcement over-consumes with abandon. ... But when service providers charge for extracting data, such as log file searches, law enforcement requests are more tailored.").

271. William J. Stuntz, The Distribution of Fourth Amendment Privacy, 67 GEO. WASH. L. REV. 1265, 1275 (1999) ("[I]f you tax a given kind of [law enforcement] behavior, you will probably see less of it.").

272. Due to the widespread popularity of prepaid phones, many communications carriers do not have a name or address on file for large numbers of their customers. As a result, it would not be possible for the carriers to notify these customers via U.S. mail (something required for surveillance of internet communications content performed under 18 U.S.C. \$2705(a)(5)). The use of the term "appropriate means" is designed to enable companies to notify their customers via a communication medium that is appropriate to the service they offer, and the contact information they have on file. This could include, for example, email, or mobile text message ("SMS"). 
(A) endangering the life or physical safety of an individual;

(B) flight from prosecution;

(C) destruction of or tampering with evidence;

(D) intimidation of potential witnesses; or

(E) otherwise seriously jeopardizing an investigation or unduly delaying a trial.

(b) PRECLUSION OF NOTICE TO SUBJECT OF GOVERNMENTAL ACCESS.-A governmental entity acting under section $[x]$ may apply to a court for an order commanding a provider of an electronic location service to whom a court order issued under section $[x]$ is directed, for such period as the court deems appropriate, not to notify any other person of the existence of the court order. The court shall enter such an order if it determines that there is reason to believe that notification of the existence of the court order will result in-

(1) endangering the life or physical safety of an individual;

(2) flight from prosecution;

(3) destruction of or tampering with evidence;

(4) intimidation of potential witnesses; or

(5) otherwise seriously jeopardizing an investigation or unduly delaying a trial.

This section requires the law enforcement agency to notify all persons whose location information it obtains within ninety days after either the disclosure of historical data or the end of prospective surveillance. Individuals shall be notified via "appropriate" means, which could be a series of text messages, an email, or a letter, depending on the contact information known to law enforcement. As with other notification statutes, the proposed section also permits the government to seek further delay of notice with cause, as well as prohibit a location provider from telling a target that her location information has been disclosed. When notifying innocent third parties that their location information was disclosed (incidentally) as part of a "broad" authorization, the governmental entity making the notification should consider language that communicates the benign nature of the disclosure.

\section{Surveillance Statistics}

When Congress created both the wiretap and pen register/trap and trace interception statutes, it mandated the annual publication of aggregate 
statistical reports" ${ }^{273}$ that were "intended to form the basis for a public evaluation of [the statute's] operation [and] will assure the community that the system of court-ordered electronic surveillance ... is properly administered." ${ }^{274}$ Since at least 1998, the Administrative Office of the United States Courts ("AO") has made copies of these reports available to the general public via its website. ${ }^{275}$ The public release of the annual report usually leads to media coverage highlighting the increased use of wiretaps. ${ }^{276}$

These statistics also provide a rich source of information for scholars wishing to study and report on the ever-increasing use of electronic surveillance. ${ }^{277}$ By comparing these reports, scholars have been able to observe several notable surveillance trends. These include that the majority of wiretaps are for drug crimes; ${ }^{278}$ that courts rarely, if ever, refuse wiretap applications; ${ }^{279}$ that the vast majority of wiretaps target mobile phones; ${ }^{280}$ and the ever-growing use of wiretaps by state law enforcement agencies. ${ }^{281}$

273. See supra note 171.

274. S. REP. NO. 90-1097, at 69 (1968), reprinted in 1968 U.S.C.C.A.N. 2112, 2185, and available at $1968 \mathrm{WL} 4956$, at $* 2185$.

275. See, e.g., Admin. Office of the U.S. Courts, 1997 Wiretap Report (1998), http://web.archive.org/web/19981206135425/www.uscourts.gov/wiretap/contents.html.

276. See, e.g., National News Briefs; Record Total of Wiretaps Was Approved by Courts, N.Y. Times (May 10, 1998), http://nyti.ms/IhNhQj; Susan Stellin, Compressed Data; Who's Watching? No, Who's Listening In?, N.Y. TIMES (June 3, 2002), http://nyti.ms/IhNp2d; Ryan Singel, Police Wiretapping Jumps 26 Percent, WIRED (Apr. 30, 2010), http://www.wired.com/ threatlevel/2010/04/wiretapping/.

277. See Cloud Based Computing Hearing, supra note 165, at 130 (oral answer from Fred Cate, Prof. and Director, Ctr. for Applied Cybersecurity Research, Ind. Univ., to Chairman Nadler) ("[Surveillance] statistics gives Congress a sound empirical basis on which to evaluate how its laws are being used and whether they need to be changed. It also provides that same information for people such as those of us gathered at this table when making recommendations to Congress. And it provides information to the public and the press so that they know how those laws are being used and to what effect."); see also Soghoian, supra note 170 .

278. Soghoian, supra note 170, at 9 ("[M]ore than 86 percent of the 2306 wiretap orders obtained [in 2009] by federal and state law enforcement agencies were sought in narcotics investigations."').

279. See id. at 6-7 ("Between 1987 and 2009, law enforcement agencies requested over 30,000 wiretap orders. ... During the more than 20 years for which public data exists, requests for wiretap orders have been rejected just 7 times, twice in 1998, once in 1996, twice in 1998, once in 2002 and once in 2005.”).

280. See id. at 7 ("96 percent (2,276 wiretaps) of all authorized wiretap for 2009 are for portable devices.").

281. See id. at 12 ("Over the last decade, the use of electronic surveillance orders has increased nationwide, although this is largely due to a massive increase in use by the states ... [California and New York] are now responsible for a combined 58 percent of all state wiretap orders."). 
While much is known about the scale and use of wiretaps and, to a lesser extent, Pen/Trap surveillance, law enforcement requests for location information are largely a "known unknown." 282 Wireless companies and their representatives have provided, at best, a partial picture whose details emerge only through Freedom of Information Act requests and other investigative reporting techniques by privacy advocates. ${ }^{283}$ That picture is not sufficiently clear to guide Congress regarding the use of this surveillance technique. ${ }^{284}$ To remedy this deficiency, we propose a specific reporting requirement that will enable Congress to know as much about the state of location surveillance as it currently knows about wiretaps and would, as Senator Patrick Leahy has described, provide a "far more reliable basis than anecdotal evidence on which to assess law enforcement needs and make sensible policy in this area." 285 This standard could be drafted as follows:

(a) GENERAL RULEMAKING AUTHORITY FOR REPORTS UNDER THIS SECTION.-The Director of the Administrative Office of the United States Courts may make rules regarding the content and form of the reports required under this section.

(b) REPORTS CONCERNING DISCLOSURES.-

(1) TO ADMINISTRATIVE OFFICE.-Not later than 30 days after the issuance or denial of an order under this chapter compelling the disclosure of location information, the issuing or denying judge shall report to the Administrative Office of the United States Courts-

(A) the fact that an order was applied for;

(B) the type of order applied for;

(C) whether the order was granted as applied for, was modified, or was denied;

(D) whether the court also granted delayed notice and the number of times such delay was granted;

(E) the offense specified in the order or application, or extension of an order;

282. News Transcript, U.S. Dep't of Defense, DoD News Briefing-Secretary Rumsfeld and Gen. Myers (Feb. 12, 2002), available at http://www.defense.gov/transcripts/ transcript.aspx?transcriptid=2636 ("[T] here are known knowns; there are things we know we know. We also know there are known unknowns; that is to say we know there are some things we do not know."); see also supra Part I (discussing details about what is known regarding the scale of location surveillance).

283. See generally Soghoian, supra note 170.

284. Id.

285. 145 CONG. REC. 31,311 (1999) (statement of Sen. Leahy). 
(F) the identity, including district where applicable, of the applying investigative or law enforcement agency making the application and the person authorizing the application; and

(G) the type of information or records sought in the order.

(2) TO CONGRESS.-In April of each year the Director of the Administrative Office of the United States Courts shall report to Congress with respect to the preceding calendar year-

(A) the overall total number of each of the events described in the subparagraphs of paragraph (1), regarding applications reported to that Office; and

(B) a summary and analysis of the data described in paragraph (1).

(c) PROVIDER REPORTING REQUIREMENTS.-

(1) TO ADMINISTRATIVE OFFICE.-Except as provided in paragraph (2), in January of each year each provider of an electronic location service shall report with respect to the preceding calendar year to the Administrative Office of the United States Courts-

(A) the number of legal demands and emergency requests received from Federal law enforcement agencies during the preceding calendar year for location information;

(B) the number of legal demands and emergency requests received from State, local, and tribal law enforcement agencies during the preceding calendar for location information; and

(C) the number of accounts about which location information was disclosed, specifying the numbers disclosed pursuant to legal demand and the numbers disclosed voluntarily, to Federal, State, local, or tribal law enforcement agencies.

(2) EXCEPTIONS. - The requirement of paragraph (1) does not apply to a provider of an electronic location service that, during the reporting period-

(A) received fewer than 50 requests combined from law enforcement agencies; or

(B) disclosed account information concerning fewer than 100 subscribers, customers, or other users; or

(C) had fewer than 100,000 total customers or subscribers at the end of the calendar year. ${ }^{286}$

286. The purpose of these statistics is to provide Congress, scholars, and the general public with information necessary to determine the scale of surveillance and to observe 
(3) COMPENSATION.-The Director of the Administrative Office of the United States Courts shall provide reasonable compensation to a provider for the costs of compiling a report required under this subsection. ${ }^{287}$

(4) CONFIDENTIALITY OF IDENTITY OF SERVICE PROVIDERS.- The Director of the Administrative Office of the United States Courts shall establish procedures to prevent the release to the public of the identity of service providers with respect to disclosures they make under this subsection. ${ }^{288}$

(5) TO CONGRESS.-In April of each year, the Director of the Administrative Office of the United States Courts shall report to Congress with respect to the preceding calendar year-

(A) the total numbers of legal demands and of disclosures required to be reported under paragraph (1); and

(B) a summary and analysis of the information required to be reported by paragraph (1), but without disclosing the identity of any service

general trends. Information from small providers who receive just a handful of requests per year will not significantly aid in the ability to observe such trends, in comparison to the tens of thousands of requests received by large providers. Furthermore, this notice requirement, while modest, could still be quite burdensome for a small provider. It is for this reason that we have opted to exempt such providers from the statistical reporting requirements.

287. As a general rule, companies are not in favor of regulations that are costly to comply with. Although we do not believe that the cost of compiling and submitting these reports will be exceedingly expensive (particularly given that Google already provides some data voluntarily), we have included a compensation provision to avoid giving companies a reason to lobby against it. We believe that the data that will be made public as a result of this provision is worth the modest cost to the taxpayer.

288. Although most large internet and telecommunications companies that handle user data receive both compulsory and voluntary location data requests from the government, few like to discuss the topic publicly. As such, many companies might vigorously oppose this statistical reporting requirement if it would mean that their names would be associated with the data that eventually becomes published. In order to respond to companies' concerns, this provision has been drafted to ensure that identities of the companies will remain confidential: only aggregate statistics will be published. In March 2010, Microsoft Associate General Counsel Mike Hintze told a reporter at Wired that the reason Microsoft does not publish statistical data regarding the number of legal requests the company receives for customer information is due to the fear of negative publicity. "We would like to see more transparency across the industry," Hintze said. "But no one company wants to stick its head up to talk about numbers." Ryan Singel, Google, Microsoft Push Feds To Fix Privacy Laws, WirED (Mar. 30, 2010), http://www.wired.com/threatlevel/2010/03/google-microsoft-ecpa/; see also Letter from Michael T. Gershberg, Counsel to Yahoo! Inc, to William Bordley, FOIPA Officer, U.S. Marshals Serv. 9 (Sept. 15, 2009), available at http://cryptome.org/yahoo-pricelist-letter.pdf ("[Surveillance pricing] information, if disclosed, would be used to 'shame' Yahoo! and other companies — and to 'shock' their customers. Therefore, release of Yahoo!'s information is reasonably likely to lead to impairment of its reputation for protection of user privacy and security, which is a competitive disadvantage for technology companies."). 
provider with respect to the disclosures to law enforcement that service provider made.

This section creates a new statistical surveillance report for Congress that documents the issuance of orders compelling the disclosure of location information. The $\mathrm{AO}^{289}$ will compile the annual report based on information submitted to it by judges who have issued orders in response to government applications to compel location information. The AO will then submit the compiled information in a report to Congress. This section also requires providers of an electronic location service (other than those falling below a de minimis threshold) to submit annual reports regarding the number of compelled and voluntary disclosures of location information they have made to the $\mathrm{AO}{ }^{290}$ The $\mathrm{AO}$ will then compile the data collected, produce a statistical summary containing no reference to the names of individual providers, and submit the information in a report to Congress.

\section{CONCLUSION}

The use of location information by law enforcement agencies is common and is becoming more so as technology improves and produces more accurate and precise location data. The legal mystery surrounding the proper law enforcement access standard for prospective location data remains unsolved and has created, along with conflicting rulings over the appropriate law enforcement access standard for both prospective and historical location data, a messy, inconsistent legal landscape where even judges in the same district may require law enforcement to meet different standards before authorizing law enforcement to compel location data. As courts struggle with these intertwined technology, privacy, and legal issues, some judges are expressing concern over the scope of the harms, from specific and personal to general and social, presented by unfettered government collection and use of location data.

289. The AO is the preferred entity to manage and execute this task because it is an objective, neutral organization and because it has historically produced the annual Wiretap Report (part of the Omnibus Crime Control and Safe Streets Act of 1968) in an accurate, timely manner. See 145 CONG. REC. 31,311 (1999) (statement of Sen. Leahy) ("The AO has done an excellent job of preparing the wiretap reports."). Placing the reporting burden with the $\mathrm{AO}$ also prevents law enforcement from complaining that the reporting requirements are turning "crimefighters into bookkeepers." House Judiciary 2000 ECPA Hearing, supra note 175, at 39 (statement of Kevin DiGregory, Deputy Assoc. Attorney Gen., Dep’t of Justice).

290. The AO is only capable of compiling information on court orders for location information. Statistical data for voluntary disclosures made in emergencies can only come from the providers or law enforcement, and so we have opted to place this burden on the providers, who are then compensated for their trouble. 
This Article proposes model law enforcement access standards and downstream privacy protections for location information. This proposal attempts to (1) articulate clear rules for courts to apply and law enforcement agents and industry to follow; and (2) strike a reasonable balance among the interests of law enforcement, privacy, and industry. We believe that our location information framework could form a solid basis for legislation because, among other things, when measured against the current state of the law, it improves the position of all stakeholders appreciably. Industry gains clear rules to follow and is not overly burdened or exposed by reporting requirements. Law enforcement gains clear rules to follow that will not unduly limit their investigative activities, especially in light of certain existing policies voluntarily adopted by the DOJ. Indeed, law enforcement's ability to acquire prospective location information to find individuals who have committed, are committing, or are about to commit a crime, when the location information itself is not evidence of a crime, is arguably improved by these proposed access standards. Moreover, law enforcement participation in a system that features tighter standards for initial access, as well as increased downstream privacy protections like minimization and notice, will promote increased public trust in the integrity of the system and a corresponding increase in law enforcement's own credibility.

While many privacy advocates have lobbied for a probable cause standard for all law enforcement access to location data, we have illustrated that this is not a realistic legislative goal in the current political climate or any immediately foreseeable one. Law enforcement will successfully argue that such a standard will unduly limit its investigative activities, including the ability to exclude someone from an investigation and spare her any unnecessary further inquiry into her personal life. Our proposal, however, offers privacy advocates clear rules that improve upon the current D Order standard and ensures that a probable cause standard will govern all law enforcement compelled disclosures of prospective cell phone location data. Moreover, this privacy framework offers privacy advocates a policy more protective than any threshold access standard alone can provide: downstream privacy protections that, among other things, ensure greater transparency and congressional oversight and minimize government authorities' retention of location data. As a legislative strategy, then, we submit that privacy advocates will stand on much firmer ground in supporting access standards aimed at a reasonable, legitimate balancing of stakeholder equities that also include downstream privacy protections. While privacy advocates can continue to fight for higher access standards for all location data in the courts, their constituents will not benefit from valuable downstream protections unless Congress includes them as part of reasonable, palatable ECPA legislative 
reform. Our solution follows the suggestions of some jurists who have considered the potential social harms posed by location-based technologies and services: that Congress may be best suited to address these issues. We agree and offer the foregoing proposal as a strong initial step in that direction. $^{291}$

291. During the writing of this Article, three bills in the 112th Congress were introduced proposing new law enforcement access standards for location data. See S. 1011, 112th Cong. (2011); S. 1212, 112th Cong. (2011); and H.R. 2168, 112th Cong. (2011). None of these bills currently contain downstream privacy protections. Two of the bills, S. 1212 and H.R. 2168, require a Rule 41 "probable cause" standard for all law enforcement compelled disclosures of location data, including the use of GPS tracking devices placed on cars. While S. 1011 allows law enforcement to compel historical location data with a D Order, there is no scope element addressing whether there is a sufficient nexus between the alleged or suspected criminal activity and the scope of the location data requested. See supra Sections III.C.1, III.C.2. S. 1011, like the two other bills, requires a Rule 41 "probable cause" showing for law enforcement to compel prospective data (including the use of GPS tracking devices) but similarly does not take into account the "probable cause of what" problem that may inhibit law enforcement from acquiring the current or prospective location of a subject who, for example, has committed a past crime when the subject's current or prospective location is not itself evidence of a crime. 
